Nuclear Reactor Technology and

Scientific Computations

WSRC-RP-92-973

Key Words: PRA

Source Term Analysis

Safety Analysis

Risk Assessment

Severe Accidents

Retention: Lifetime

\title{
Input To The Prast Computer Code Used In The SRS Probabilistic Risk Assessment
}

\author{
by \\ D. P. Kearnaghan
}

Issued: October 15, 1992

Westinghouse Savannah River Company

Savannah River Site

Alken, SC 29808

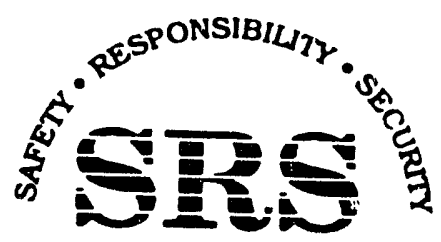

SAVANNAH RIVER SITE

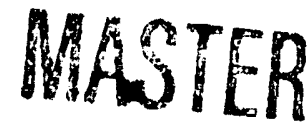

PREPARED FOR THE U.S. DEPARTMENT OF ENERGY UNDER CONTRACT NO. DE-AC09-695R18035 


\section{PROJECT: PRA}

DOCUMENT: WSRC-92-RP-973

TILE: Input to the PRAST Computer Code as used in the SRS Probabilistic Risk Assessment

Approvals:

W.8. Aaker

W. H. Baker, Technical Reviewer

A. Paiter

R. T. Bailey fechnical Reviewer

Tani o.kul

K. R. O'Kula, Manager

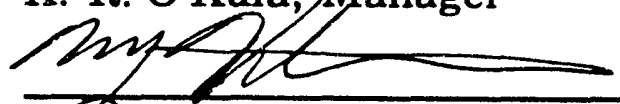

M. J. Hitchler, Manager
Date: $8 / 24 / 92$

Date: $\quad 8 / 24 / 92$

Date: $\quad 7-30-92$

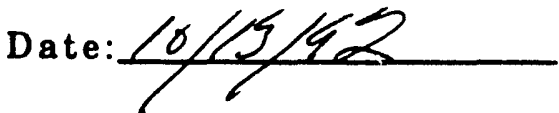


This Page Intentionally Left Blank 


\section{ABSTRACT}

The PRAST (Production Reactor Algorithm for Source Terms) computer code was developed by Westinghouse Savannah River Company (WSRC) and Science Application International Corporation (SAIC) for the quantification of source terms for the SRS Savannah River Site (SRS) Reactor Probabilistic Risk Assessment (PRA). PRAST requires as input a set of release fractions, decontamination factors, transfer fractions and source term characteristics that accurately reflect the conditions that are evaluated by PRAST. This document links the analyses which form the basis for the PRAST input parameters. In addition, it gives the distribution of the input parameters that are uncertain and considered to be important to the evaluation of the source terms to the environment. 
WSRC-RP-92-973

This Page Intentionally Left Blank 


\section{ACKNOWLEDGEMIENTS}

The Production Reactor Algorithm for Source Terms (PRAST) Computer Code and its input parameters were developed by Westinghouse Savannah River Company (WSRC) and Science Application International Corporation (SAIC) as a part of the SRS $\mathrm{K}$ Reactor Level 2 PRA analysis. The individuals who made significant contributions to the development of the PRAST input parameters are given below.

WSRC

W. H. Baker

M. D. Brandyberry

K. R. O'Kula

R. S. Wittman

N. D. Woody
SAIC

C. N. Amos

D. R. Bradley

W. L. Ferrell

P. R. McClure

C. T. Stockman

K. C. Wagner

J. J. Weingardt 
WSRC-RP-92-973

This Page Intentionally Left Blank 


\section{TABLE OF CONTENTS}

Page

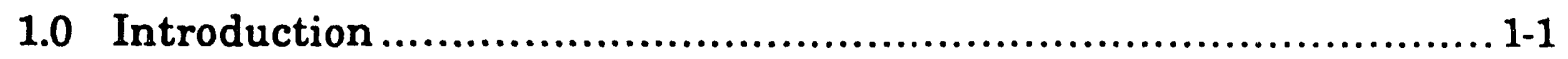

2.0 Background of the PRAST Computer Code ............................. 2-1

2.1 Fission Product Groups................................................ 2-1

2.2 Fission Product Reservoirs ........................................... 2-2

2.3 PRAST Time Periods........................................................2-4

2.4 PRAST Input Parameters............................................. 2-6

3.0 PRAST Parameter Classes............................................... 3-1

4.0 Parameter Data Justifications ........................................ 4-1

4.1 Release Fractions ...................................................

4.1.1 Release Fractions From Fuel.......................................4-1

4.1.1.1 Fuel Melt.......................................................4-2

4.1.1.2 Heat up of the Core on the Vessel Bottom..................... 4-4

4.1.1.3 Release Fractions During Steam Explosions................45

4.1.1.4 Release Fractions During Molten Core Concrete Interactions............................................................4-6

4.1.2 Release Fractions From Structural Surfaces..................4-6

4.1.2.1 Release Fractions From Primary System Surfaces...... 4-6

4.1.2.2 Release Fractions From Filters............................ 49

4.1.3 Release Fractions From Contaminated Water ..................4-10

4.1.3.1 Release Fractions From Primary System Water..........4-10

4.1.3.2 Release Fractions Frorn Confinement Water ............4-10

4.1.3.3 Release Fractions From Water Outside Confinement.................................................4-11

4.2 Decontamination Factors...............................................4-13 


\section{TABLE OF CONTENTS (CONTINUED)}

Page

4.2.1 Decontamination Factors of Overlying Water $.4-13$

4.2.1.1 Decontamination Factors of Primary System Water ....4-13

4.2.1.2 Decontamination Factors of Water Overlying MCCI....4-15

4.2.2 Decontamination Factors of Structures.

$.4-16$

4.2.2.1 Decontamination Factors of Primary System Structures ...................................................4-16

4.2.2.2 Decontamination Factors of Confinement Structures .420

4.2.2.3 Decontamination Factors of Reactor Room Sprays........4-23

4.2.2.4 Decontamination Factors of AACS Filters.................4-25

4.3 Transfer Fractions..................................................26

4.3.1 Early Phase Transfer Fractions ...............................4-26

4.3.2 Intermediate Phase Transfer Fractions.......................4-27

4.3.3 Late Phase Transfer Fractions.....................................4-27

4.4 Source Term Characteristics ....................................28

4.4.1 Release Timings .............................................28

4.4.2 Release Durations................................................4-28

4.4.2.1 Duration of Time Period 1 (Fuel Melt) ....................4-29

4.4.2.2 Duration of Time Period 2 (Fuel Debris Heat Up)........4-29

4.4.2.3 Duration of Time Period 3 (Vessel Failure)................429

4.4.2.4 Duration of Time Period 4 (Core Concrete Ir teraction) ...........................................4-29

4.4.2.5 Duration of Time Period 5 (Delayed Releases) ............4-30

4.4.3 Elevation of Release ...........................................4-30

4.4.4 Thermal Energy of Release .................................4-30 


\section{TABLE OF CONTENTS (CONTINUED)}

Page

4.5 Chemical Characteristics of the Release...............................4-32

5.0 Distributions of Sampled Input Parameters ............................ 5-1

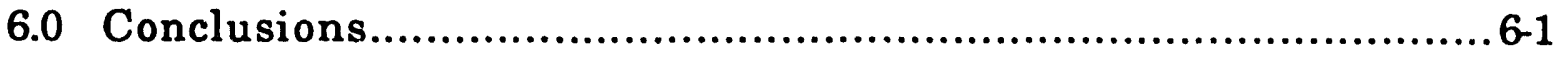

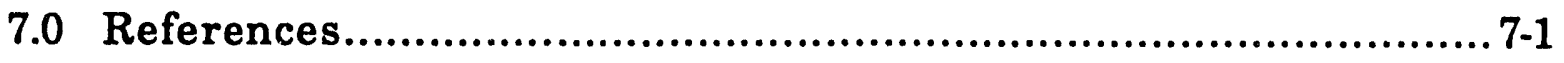

Appendix A Listing of the PRAST Parameter Input File ................ A-1

Appendix B Distributions of the Sampled PRAST Input

Parameter Values .............................................

B.1 Release Fractions During Fuel Melt ...............................3

B.2 Release Fractions During Heat Up of Core .........................5

B.3 Release Fractions During Molten Core-Concrete Interactions ........................................................

B.4 Release Fractions Primary System Structures ......................B-8

B.5 Release Fractions From Filters ......................................

B.6 Release Fractions From Contaminated Water.................... B-10

B.7 Decontamination Factors of Primary System Water.............. B-11

B.8 Decontamination Factors of Water Overlying MCCI .............. B-12

B.9 Decontamination Factors of Primary System Structures ........ B-15

B.10 Decontamination Factors of Process Room Sprays for Iodine ... B-18

B.11 Early Transfer Fractions ........................................... B-19

B.11 Release Timing ................................................ B-20

B.12 Fraction of Iodine Released in the Chemi:?l Form ............... B-21 
WSRC-RP-92-973

This Page Intentionally Left Blank

zii 


\section{LIST OF TABLES}

Page

2-1 PRAST Fission Product Groups ................................ 2-2

2-2 PRAST Time Period Definitions .................................... 2-5

2-3 Source Term Parameter Definitions...................................2-7

2-4 Source Term Parameter Categories .................................. 2-9

4-1 Boiling Points of the Ten PRAST Element Groups ................ 4-1

4-2 Release Fractions During Fuel Meilt ............................4-4

4-3 Release Fractions During Core Debris Heat Up...................45

4-4 Release Fractions During Core-Concrete Interactions ............4-6

45 Revolatilization Fractions of Fission Products from Primary System Surfaces ......................................................49

46 Late Filter Release Fractions ....................................4-10

4-7 Very Late Contaminated Water Revolatilization Release Fractions........................................................4-12

4-8 Decontamination Factors of Primary System Water.................4-14

4-9 Decontamination Factors of Water Overlying MCCI ..............4-16

4-10 Decontamination Factors of Primary System Structures .........4-20

4-11 Decontamination Factors of Above Grade Confinement

Structures Without Sprays...............................................4-21

4-12 Decontamination Factors of Above Grade Confinement Structures With Sprays .........................................4-22

4-13 Decontamination Below Grade Confinement Structures ........4-23

4-14 Decontamination Factors of Process Room Sprays................4-24

4-15 Decontamination Factors of AACS Filters ..........................4-25

4-16 Fraction of Fission Products Purged from the Confinement by the Start of the Late Phase................................................4-26

4-17 Fraction of Fission Products that Bypass the Confinement Filters in the Late Phase. 


\section{LIST OF TABLES (CONTINUED)}

Page

4-18 Thermal Energy Associated with Fission Product Release 4-28

B.1-1 Distribution of Release Fractions During a Non-Energetic Melt

B.1-2 Distribution of Release Fractions During Melt for a Recriticality Event

B.1-3 Distribution of Release Fractions During Melt for a Power Excursion B-4

B.2-1 Distribution of Release Fractions During Core Debris Heatup (1700 K) .

B.2-2 Distribution of Release Fractions During Core Debris Heatup (1400 K) .

B.2-3 Distribution of Release Fractions During Core Debris Heatup (1000 K) B-6

B.3-1 Distribution of Release Fractions During MCCI...................B-7

B.4-1 Distribution of Primary System Revolatilization Release Fractions High Revolatilization

B.4-2 Distrii)ution of Primary System Revolatilization Release Fractions Moderate Revolatilization. B-8

B.5-1 Distribution of Release Fractions From Filters - Filter Burn .....B-9

B.5-2 Distribution of Release Fractions From Filters - Filter Desorption

B.6-1 Distribution of Release Fractions From Contaminated

Water.

B.7-1 Distribution of Decontamination Factors of Primary SystemWater.

B.8-1 Distribution of Decontamination Factors Overlying MCCI (Dry) B-12

B.8-2 Distribution of Decontamination Factors of Water Overlying MCCI (Submerged). 


\section{LIST OF TABLES (CONTINUED)}

Page

B.8-3 Distribution of Decontamination Factors of Water Overlying MCCI (Flooded).................................................... B-14

B.9-1 Distribution of Decontamination Factors of Primary System Structures (Water in Vessel) .................................... B-15

B.9-2 Distribution of Decontamination Factors of Primary System Structures (Dry Vessel) ............................................... B-16

B.9-3 Distribution Decontamination Factors of Primary System Structures (Vessel Water Energetically Expelled)................ B-17

B.10-1 Distribution of Decontamination Factors of Process Room Sprays for Iodine .............................................. B-18

B.11-1 Distribution of Early Filter Bypass Fraction (Partial Bypass)... B-19

B.12-1 Initial Release Timing for Delayed Release (Seconds) ........... B-20

B.13-1 Distribution of Fraction of Iodine Released in the Elemental Form ................................................................ B-21 
WSRC-RP-92-973

This Page Intentionally Left Blank 
WSRC-RP-82-973

\section{LIST OF FIGURES}

Page

2-1 PRAST Fission Product Reservoirs ................................. 2-3 
WSRC-RP-92-973

This Page Intentionally Left Blank

rviii 


\subsection{INTRODUCTION}

The approach taken to perform the Savannah River Site (SRS) Probabilistic Risk Assessment (PRA) makes use of the methods developed for the USNRC during the NUREG-1150 [1] program for assessment of commercial reactor operation risk due to severe accidents. The Level 1 analysis utilizes sequence event trees quantified with fault trees and plant system data to track system failures and identify core melt sequences. The sequences which result from the Level 1 analysis are then grouped on the basis of similarities in the plant's condition. These groups are referred to as plant damage states (PDSs). The Level 2 analysis evaluates the progression of the core melt accident utilizing an accident progression event tree (APET) to probabilistically track accident sequence progrission. Radiological source terms are then assigned to groups of accident progressions that have similar characteristics. Finally, the Level 3 analysis calculates consequences for each of the source terms defined by the Level 2 analysis.

Within the Level 2 PRA analysis, the release to the environment for accident sequence groups is quantified. Specifically, the source terms to the environment for accident progression sequences that have significant probabilities are determined. In this context, a source term refers to the timing, duration, elevation, magnitude, and energy characterizing the radiological release from the postulated reactor accident.

It was recognized early in the SRS PRA program that a fast running source term estimation code was needed to perform a large number of source term calculations. The XSOR codes, developed in the NUREG-1150 program, were written for the estimation of source terms due to severe accidents in commercial reactors. However, there was no such code in existence to accurately reflect conditions present in an SRS reactor during comparable challenges posed by severe accidents. To meet this need, the development of a code specific to SRS was undertaken, the Production Reactor Algorithm for Source Terms or PRAST. The PRAST code is described in great detail in WSRC-RP-92-700 [2].

The purpose of this document is to describe: (1) the calculation of PRAST input parameters; and (2) distributions assigned to the parameters. The latter are important in terms of the uncertainty analysis performed as a part of the Level 2 risk assessment. The information given in this document was used in the quantification of Revision 0 of the Level 2 PRA as described in Reference [3]. 
WSRC-RP-92-973

This Page Intentionally Left Blank 


\title{
2.0 BACKGROUND OF THE PRAST COMPUTER CODE
}

\begin{abstract}
A detailed explanation of PRAST is given in [2]. For convenience, description of the fission product groups, the fission product reservoirs, the time periods, and the input parameters are given in this section.
\end{abstract}

\subsection{Fission Product Groups}

The major component of PRAST is the tracking of the large number of isotopes that exist in an irradiated SRS Reactor core from the damaged fuel to the environment. Since many fission product isc topes are released and transported in a similar fashion, it was logical to classify the isotopes into a limited number of fission product groups.

Ten fission product groups are included in PRAST. These groups are listed in Table 2-1. In the SRS PRA analysis, it is assumed that the in-plant transport of tritium is identical to that of noble gases. Since tritium would be present as water or water vapor (HTO), much of the released tritium would probably be retained, or significantly delayed in escape to the environment. Each of the fission product groups considered has potentially different transport characteristics, so PRAST considers each of the ten groups separately.

The radionuclides in the second fission product group, iodine, are released from the fuel as elemental iodine and cesium iodide. Since the transport characteristics of elemental iodine and cesium iodide differ greatly, an eleventh fission product group which represents cesium iodid is created within PRAST. The elemental iodine is released and transported as iodine, however, the cesium iodide is released as iodine and transported as cesium (i.e., the decontamination factor (DF) of vessel water applied to iodide is equal to the DF that is applied to cesium). Thus, each of the release fraction and decontamination factor parameters in the algorithm has eleven values. The release fractions are calculated for each group separately. Eleven sets of equations are solved to predict the release fractions in PRAST. There is no similar situation with transfer fractions (i.e., the fraction of radionuclides that bypass confinement) since a single transfer fraction is applied to all radionuclides for each transfer. The release fractions of elemental iodine and cesium iodide are recombined before the results are written to the output file. The reason for recombining the eleventh group with the second group is that consequences from cesium iodide do not differ significantly from those of elemental iodine. In addition, including an additional element group would significantly increase the computer code calculational time required in the remaining steps of the PRA quantification process. 
WSRC-RP-92-973

Table 2-1. PRAST Fission Product Groups

Group

\begin{tabular}{cll} 
Number & Group Name & Constituent Elements \\
\hline 1 & Noble Gas & $\mathrm{Kr}, \mathrm{Xe}$ \\
2 & Iodine & $\mathrm{I}$ \\
3 & Cesium & $\mathrm{Cs}, \mathrm{Rb}$ \\
4 & Tellurium & $\mathrm{Te}, \mathrm{Sb}$ \\
5 & Strontium & $\mathrm{Sr}$ \\
6 & Ruthenium & $\mathrm{Mo}, \mathrm{Tc}, \mathrm{Ru}, \mathrm{Rh}$ \\
7 & Lanthanum & $\mathrm{Y}, \mathrm{Zr}, \mathrm{Nb}, \mathrm{La}, \mathrm{Pr}, \mathrm{Nd}, \mathrm{Am}, \mathrm{Cm}$ \\
8 & Cerium & $\mathrm{Ce}, \mathrm{Np}, \mathrm{Pu}$ \\
9 & Barium & $\mathrm{Ba}$ \\
10 & Tritium & $3 \mathrm{H}$ \\
& &
\end{tabular}

\subsection{Fission Product Reservoirs}

The water in the reactor vessel and the confinement as well as the reactor vessel and confinement structures are known to decontaminate airborne fission products that have been released from damaged fuel. In order to apply decontamination factors (DFs) for these potential reservoirs, the mass of fission products being affected by a particular decontaminator must be known. The system developed for the XSOR codes under the NUREG-1150 program identified locations were fission products could reside under accident conditions. PRAST was developed in a similar manner.

PRAST considers the fuel, the reactor vessel, and the confinement system as a series of reservoirs that may contain fission products. There is a total of twelve fission product reservoirs in PRAST including the environment. Figure 2-1 gives a representation of the fission product reservoirs. The core is represented three times: 1) damaged fuel in the vessel, 2) core debris on the bottom of the vessel, and 3) core debris on the confinement floor. These three locations are considered one reservoir since all three are the remains of the core and they never exist in the same time period. Transport of fission products from one reservoir to another is determined by the algorithm. Fission products that are transported out of the confinement reservoirs are assumed to be released to the environment, and therefore constitute the source term. 


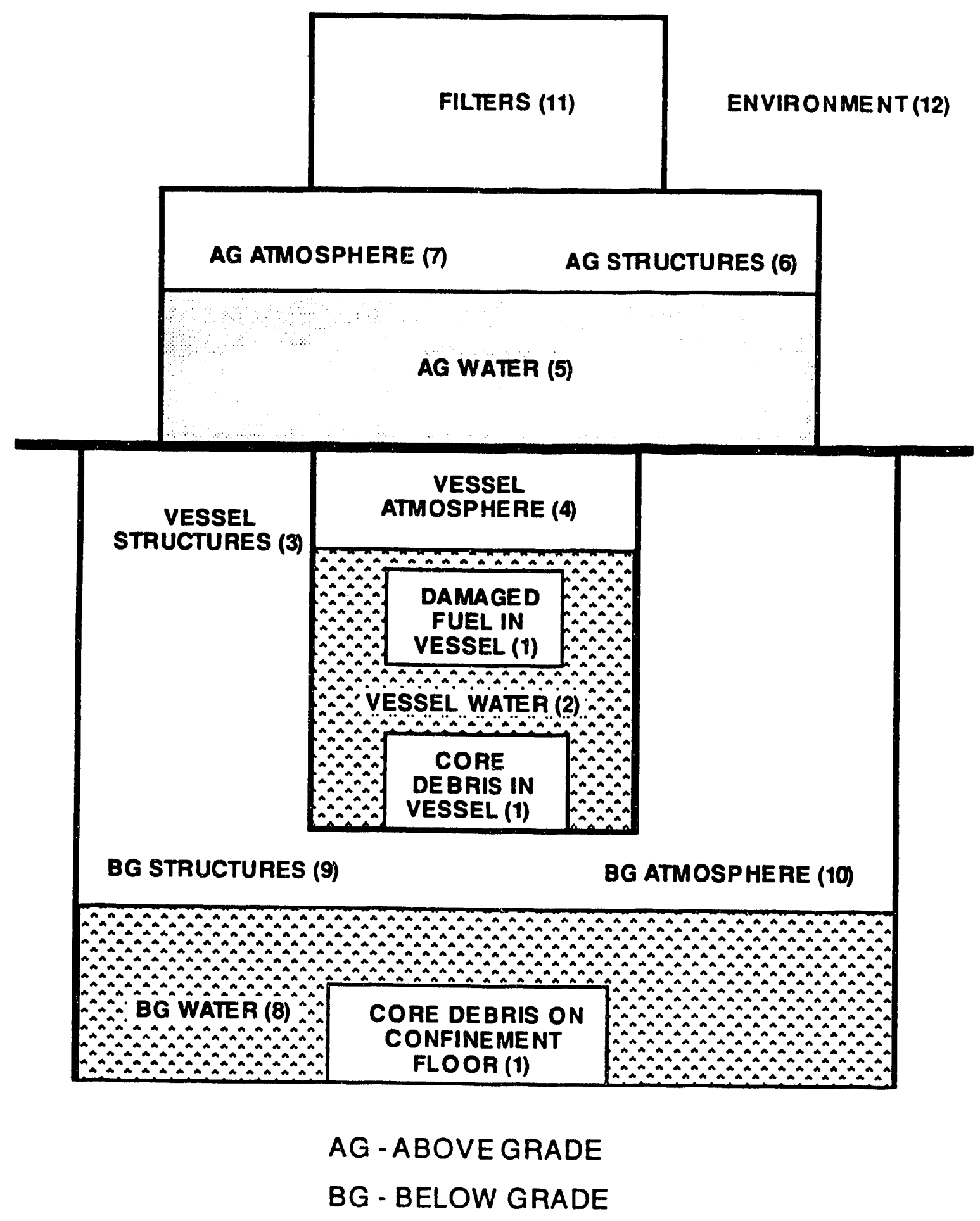

Figure 2-1. PRAST Fission Product Reservoirs 


\section{$2.3 \quad$ PRAST Time Periods}

To simplify development of the source term algorithm, the accident progression was divided into five separate time periods (shown in Table 2-2) that correspond to the last five of the six phases of the Accident Progression Event Tree (APET) described in $[3,16]$. In the APET modeling, the initial period of the early phase is melt initiation and primary system thermalhydraulics up to the point of fuel melting. Fission product release has not begun at this point, and thus, this time period is not modeled in PRAST. The specific time periods considered in PRAST were

(1) Core Meltdown, beginning with clad blistering (fission gas release) and ending when fuel debris has collected on the vessel bottom (corresponding to the second period of the APET early phase);

(2) Debris Heat Up, covering the heat up of the debris on the vessel bottom and ending with primary system failure $0^{*}$ permanent cooling of the debris (corresponding to the third period of the APET early phase);

(3) Vessel Failure, which considers the phenomena that accompany primary system failure (corresponding to the APET intermediate phase);

(4) Core-Concrete Interaction, beginning at primary system failure and extending over the time that the core debris interacts with the concrete basemat. Revolatilization from confinement structures and confinement water (due to water boil-off) may occur (corresponding to the APET late phase); and

(5) Delayed Releases, which covers the period following core-concrete interaction during which filter combustion (due to exhaust fan failure) or revolatilization of fission products absorbed in water discharged from the building may occur (corresponding to the APET long term phase). 
WSRC-RP-92-973

Table 2-2. PRAST Time Period Definitions

\section{Period}

Number

Period Title

Period Duration Definitions

1 Core Meltdown

Normal Meltdown

Recriticality Vessel Failure

Power Excursion Vessel Failure

2 Debris Heat Up

Energetic Vessel Failure

Early Vessel Failure (steam explosion in effluent pipe)

Thermal Vessel Failure

$3 \quad$ Vessel Failure

Energetic Event Occurs

No Energetic Events

4 Core-Concrete Interaction

MCCI

Late Filter Burn

Filter Desorption

$5 \quad$ Delayed Releases

Delayed Filter Burn

- Iodine Revolatilization

Time periods may be dropped from consideration or modified based on events that occur during the accident progression. Possible alterations in the the time period sequence are as follows:

(1) Vessel bottom failure during core meltdown or cooling of the core debris on the vessel bottom leads to the elimination of Period 2

(2) Non-energetic primary system failure (i.e., primary system failure neither caused nor accompanied by a steam explosion) eliminates Period 3 since the primary system failure is not accompanied by a sharp increase in fission product releases from the damaged fuel

(3) Cooling of the core debris in the reactor vessel eliminates Periods 3 and 4.

(4) Cooling of the core debris in the below-grade confinement eliminates the releases from core-concrete interaction in Period 4 
(5) Filter failure or combustion during the accident progression (i.e., through the time core-concrete interaction is terminated) eliminates Period 5. This time period is also eliminated if filter combustion never occurs.

Fission products in a reservoir at the end of one time period were considered to be present in that reservoir at the start of the next time period with two exceptions. Fission products in the vessel water during Period 3 were transferred to the water on the confinement floor. Similarly, fission products in the vessel atmosphere during Period 3 are transferred to the above grade confinement atmosphere. Primary system failure was simulated in this manner.

\section{PRAST Input Parameters}

There is a total of 28 input parameters used by PRAST. Table 2-3 gives the definitions of all of the PRAST input parameters. A listing of the categories included for each parameter is given in Table 2-4. The category given for variables which do not have any categories (one set of values) is "All Conditions".

The remainder of this document focuses on the quantification of the PRAST input parameter values. 
Table 2-3. Source Term Parameter Definitions

Variable Description

Name

TRELSE Time after scram at which release begins

VERF Release of radionuclides from fuel during fuel degradation

DFIVW Decontamination factor (DF) for the vessel water

DFIV Decontamination factor (DF) for the vessel structures

ECDF Decontamination factor (DF) for the above-grade confinement structures

ECDFMN Minimum decontamination factor (DF) for the above-grade confinement structure when sprays are operating

FRACFL Fraction of the release that exits the building during the early phase

ESPDF Decontamination factor for sprays

EBYP Fraction of release that bypasses the filters when an energetic event at vessel breach causes a breach of the confinement

ERF Release of radionuclides from fuel during fuel heat up

LRF Release of radionuclides from fuel due to molten coreconcrete interaction (MCCI)

CCIDF Decontamination factor for water overlying MCCI

VRF Revolatilization release from primary system surfaces following primary system failure

LCDF Decontamination factor for the below-grade confinement system for late releases

LBYP Fraction of release that bypasses the filters during the late phase

LFTRF Late release fraction of radionuclides from filters due to thermal degradation 
WSRC-RP.92-973

Table 2-3. Source Term Parameter Definitions (Continued)

\section{Variable Description}

Name

TPERD1 Duration of Period 1

TPERD2 Duration of Period 2

TPERD3 Duration of Period 3

TPERD4 Duration of Period 4

TPRED5 Duration of Period 5

ELEV Elevations for radionuclide release

HEATR Sensible t:eat accompanying radionuclide release (gas phase)

VLRF Late revolatilization release of radionuclides from contaminated water

FLTDF Effective decontamination factor for filters, includes nominal bypass

RFSTMX Relpoje frnm fuel of radionuclides that occurs during a whole-core steam explosion at vessel breach

MBYP Fraction of release that by-passes the filters when an energetic vessel breach does not fail the confinement building

FI2 Fraction of iodine released that is elemental iodine 
Table 2-4. Source Term Parameter Categories

Variable Categories

Name

\begin{tabular}{|c|c|c|}
\hline TRELSE & $\begin{array}{l}\text { (A) } \\
\text { (B) } \\
\text { (C) }\end{array}$ & $\begin{array}{l}\text { Immediate } \\
\text { Delayed } \\
\text { Long Delay }\end{array}$ \\
\hline VERF & $\begin{array}{l}\text { (A) } \\
\text { (B) } \\
\text { (C) }\end{array}$ & $\begin{array}{l}\text { Normal Meltdown } \\
\text { Recriticality } \\
\text { Power Excursion }\end{array}$ \\
\hline DFIVW & $\begin{array}{l}\text { (A) } \\
\text { (B) }\end{array}$ & $\begin{array}{l}\text { Water in Vessel } \\
\text { Dry Vessel }\end{array}$ \\
\hline DFIV & $\begin{array}{l}\text { (A) } \\
\text { (B) } \\
\text { (C) }\end{array}$ & $\begin{array}{l}\text { Water in Vessel } \\
\text { Dry Vessel } \\
\text { Water in Vessel but Expelled Energetically }\end{array}$ \\
\hline ECDF & $\begin{array}{l}\text { (A) } \\
\text { (B) } \\
\text { (C) } \\
\text { (D) } \\
\text { (E) } \\
\text { (F) }\end{array}$ & $\begin{array}{l}\text { Building Failure } \\
\text { Building Breach with Filter Damper Closed } \\
\text { Building Breach with Filter Damper Open } \\
\text { AACS Fans Operating } \\
\text { Natural Convection Flow Through Confinement Only } \\
\text { Filter Damper Closed }\end{array}$ \\
\hline ECDFMN & $\begin{array}{l}\text { (A) } \\
\text { (B) } \\
\text { (C) } \\
\text { (D) } \\
\text { (E) }\end{array}$ & $\begin{array}{l}\text { Building Failure } \\
\text { Building Breach with Filter Damper Closed } \\
\text { Building Breach with Filter Damper Open } \\
\text { AACS Fans Operating } \\
\text { Natural Convection Flow Through Confinement Only } \\
\text { Filter Damper Closed }\end{array}$ \\
\hline FRACFL & $\begin{array}{l}\text { (A) } \\
\text { (B) } \\
\text { (D) } \\
\text { (E) } \\
\text { (F) }\end{array}$ & $\begin{array}{l}\text { Building Failure } \\
\text { Building Breach with Filter Damper Closed } \\
\text { Building Breach with Filter Damper Open } \\
\text { AACS Fans Operating } \\
\text { Natural Convection Flow Through Confinement Only } \\
\text { Filter Damper Closed }\end{array}$ \\
\hline
\end{tabular}


Table 2-4. Source Term Parameter Definitions (Continued)

Variable Categories

Name

ESPDF (A) Building Failure

(B) Building Breach with Filter Damper Closed

(C) Building Breach with Filter Damper Open

(D) AACS Fans Operating

(E) Natural Convection Flow Through Confinement Only

(F) Filter Damper Closed

EBYP (A) Complete Bypass

(B) Partial Bypass

(C) No Bypass

ERF (A) Debris to Steel Melt Temperature

(B) Debris to Structural Failure Temperature

(C) Debris to Two Phase Temperature

LRF (A) All Conditions

CCIDF (A) No Molten-Core Concrete Interactions (MCCI)

(B) Dry MCCI ( $\leq 8$ inches of overlying water)

(C) Submerged MCCI ( $\leq 3$ feet of overlying water)

(D) Flooded MCCI ( $>3$ feet of overlying water)

VRF

(A) High Release

(B) Moderate Release

LCDF (A) High Decontamination

(B) Moderate Decontamination

(C) No Decontamination

LBYP (A) Complete Bypass (100\%)

(B) High Eypass $(80-90 \%$

(C) Moderate Bypass (60\%)

(D) Low Bypass (20-30\%)

(E) Very Low Bypass (10\%)

(F) No Bypass

LFTRF (A) Filter Burn

(B) Filter Desorption 
Table 2-4. Source Term Parameter Definitions (Continued)

\begin{tabular}{|c|c|c|}
\hline $\begin{array}{l}\text { Variable } \\
\text { Name }\end{array}$ & Cate & gories \\
\hline TPERD1 & $\begin{array}{l}\text { (A) } \\
\text { (B) } \\
\text { (C) }\end{array}$ & $\begin{array}{l}\text { Normal Meltdown } \\
\text { Recriticality } \\
\text { Power Excursion }\end{array}$ \\
\hline TPERD2 & $\begin{array}{l}\text { (A) } \\
\text { (B) } \\
\text { (C) }\end{array}$ & $\begin{array}{l}\text { Energetic Vessel Failure } \\
\text { Early Versel Failure } \\
\text { Thermal Vessel Failure }\end{array}$ \\
\hline TPERD3 & $\begin{array}{l}\text { (A) } \\
\text { (B) }\end{array}$ & $\begin{array}{l}\text { Energetic Event Occurs } \\
\text { No Energetic Event }\end{array}$ \\
\hline TPERD4 & $\begin{array}{l}\text { (A) } \\
\text { (B) } \\
\text { (C) }\end{array}$ & $\begin{array}{l}\text { MCCI } \\
\text { Filter Burn } \\
\text { Filter Desorption }\end{array}$ \\
\hline TPRED5 & $\begin{array}{l}\text { (A) } \\
\text { (B) }\end{array}$ & $\begin{array}{l}\text { Filter Burn } \\
\text { Iodine Revolatilization }\end{array}$ \\
\hline ELEV & $\begin{array}{l}\text { (A) } \\
\text { (B) } \\
\text { (C) }\end{array}$ & $\begin{array}{l}\text { Release at Ground Level } \\
\text { Release at Roof Level } \\
\text { Release at Stack Level }\end{array}$ \\
\hline HEATR & $\begin{array}{l}\text { (A) } \\
\text { (B) } \\
\text { (C) } \\
\text { (D) } \\
\text { (E) } \\
\text { (F) } \\
\text { (G) } \\
\text { (H) } \\
\text { (I) } \\
\text { (J) }\end{array}$ & $\begin{array}{l}\text { Normal Filtration } \\
\text { Steam Explosion Occurs } \\
\text { Power Excursion Occurs } \\
\text { Above Grade Natural Convection } \\
\text { Filter Desorption } \\
\text { Filter Burn } \\
\text { Energetic Hydrogen Burn } \\
\text { Continuous Hydrogen Burn } \\
\text { Uncovered MCCI } \\
\text { Unused at this time }\end{array}$ \\
\hline
\end{tabular}


Table 2-4. Source Term Parameter Definitions (Continued)

\begin{tabular}{|c|c|c|}
\hline $\begin{array}{l}\text { Variable } \\
\text { Name }\end{array}$ & Cate & sories \\
\hline VLRF & (A) & All Conditions \\
\hline FLTDF & (A) & All Conditions \\
\hline RFSTMX & (A) & All Conditions \\
\hline MBYP & (A) & All Conditions \\
\hline FI2 & (A) & All Conditions \\
\hline
\end{tabular}


WSRC-RP-92-973

\subsection{PRAST PARAMETER ClASSES}

There is a total of 28 input parameters used by PRAST. The PRAST input parameters are divided into five classes: Release Fractions, Decontamination Factors, Transfer Fractions, Source Term Characteristics, and Chemical Chacteristics of the Release.

A release fraction is simply the fraction of a radionuclide that is released from a fission product reservoir (e.g., the fuel) during a given time period. A release fraction is specified for each element group. Some of the release fraction parameters have multiple categories to discriminate between different accident scenarios. There are seven release fractions input to PRAST. Four of the seven describe fission product releases from the reactor core or core debris. The other three describe revolatilization releases from the primary system surfaces, the contaminated water (which escapes confinement), and the filters.

A decontamination factor is the ratio of the fission product mass that enters a reservoir, to the mass that exits reservoir for a given time period. A decontamination factor is specified for each element group. Some of the decontamination factor parameters have multiple categories to discriminate between different accident scenarios. There are eight decontamination factors input to PRAST. These parameters describe the fission product decontamination due to the vessel water, the primary system structures, the confinement structures, the confinement sprays, the water overlying core concrete interactions, and the confinement filters.

A transfer fraction is the fraction of fission product mass that moves from one reservoir to another reservoir during a given time period. A single transfer fraction is applied to all element groups (i.e., all element groups are assumed to transfer from one reservoir to another at the same rate for a given situation). Some of the transfer fraction parameters have multiple categories to discriminate between different accident scenarios. There are four transfer fractions input to PRAST. These parameters describe the transfer of fission products through the confinement early and late in the accident progression. There are also transfer fractions which describe the fraction of fission products which bypass the filters early and late in the accident progression.

There are nine source term characteristics input to PRAST. They describe the timing, duration, thermal energy, and elevation of the fission product releases to the environment. This information does not affect the magnitude of the fission product release to the environment but it does provide data necessary for the calculation the consequences of an accident scenario.

The Chemical Chacteristics of the Release class contains one parameter: the fraction of iodine that transports as a vapor. 
This Page Intentionally Left Blank 


\subsection{PARAMETER DATA JUSTIFICATIONS}

The assumptions and/or justifications for the assignment of the PRAST input parameters are given in this section.

\subsection{Release Fractions}

PRAST requires as input the fraction of release from fuel, structural surfaces, and contaminated water. In a postulated severe accident, fission products could be released to the confinement atmosphere from fuel during intial meltdown, heat up on the bottom of the vessel, steam explosions, and molten core concrete interactions. Revolatilization of fission products deposited on primary and confinement structural surfaces and in water (in-vessel and ex-vessel) may also contribute to the radionuclides in the confirement atmosphere. These subjects, as they relate to PRAST, are discussed in the following sections.

\subsubsection{Release Fractions From Fuel}

The release fractions from fuel are based on experimental data, MELCOR/SR calculations and engineering judgement based on the boiling point of the element group. The following PRAST parameters are described

Table 4-1. Boiling Points of the Ten PRAST Element Groups

\begin{tabular}{clc} 
Number & Group Name & Boiling Point (K) \\
\hline \hline & & \\
1 & Noble Gas & 166 \\
2 & Iodine & 457 \\
3 & Cesium & 951 \\
4 & Tellurium & 1263 \\
5 & Strontium & 1657 \\
6 & Ruthenium & 4173 \\
7 & Lanthanum & 3730 \\
8 & Cerium & 3699 \\
9 & Barium & 1913 \\
10 & Tritium & 373 \\
\hline
\end{tabular}


in this section: 1) verf - release from fuel during melt, erf - release from fuel during debris heat up, 3) rfstmx - release from fuel during a steam explosion, and 4) $\mathrm{lrf}$ - release from fuel during molten core concrete interaction (MCCI). The boiling points of each of the ten element groups are shown in Table 4-1.

\subsubsection{Fuel Melt}

The input parameter which gives the release fractions of fission products from fuel during fuel melt is verf. This parameter has a value for each of the ten element groups in three possible scenarios: 1) non-energetic melt, 2) recriticality involving 25 percent of the core, and 3) power excursion involving 10 percent of the core. These values are given in Table 4-2.

Most postulated severe accident sequences in the SRS reactors involve the formation of molten aluminum alloy pools. These pools may form after fuel assemblies melt and relocate to the reactor vessel bottom or to the reactor outlet piping. They are generally composed of uranium and aluminum from the fuel assemblies, lithium from targets, and fission products. Because the U-Al fuel melts at low temperatures (relative to LWR fuel) and quickly relocates, most volatile fission products (with the exception of noble gases) remain in the fuel at the time of pool formation. Consequently, fission product releases during the molten pool phase of the accident tend to dominate releases from all other phases.

Releases (for a non-eneregetic melt) rrom intact assemblies have been estimated by applying the CORSOR-M model [18]. CORSOR-M is a correlation of release data fit to an Arrhenius expression, which defines the release rate as a function of temperature for a variety of radionuclide species. This model has been correlated to data derived from experiments performed at Oak Ridge National Laboratory (ORNL) [19] and Hanford [20]. CORSOR-M has been used extensively to model releases from LWR fuel. Its applicability to metal fuels is not fully substantiated, but given the low releases predicted for the assembly melt phase, additional effort to refine the model is unwarranted.

The release fractions during fuel melt that includes a recriticality event were calculated by assuming that 25 percent of the core reaches $2000 \mathrm{~K}$ for a short period of time, and the remainder of the core is at the relocation temperature of $950 \mathrm{~K}$ [3]. In other words, the release fraction is the release fraction for a normal melt plus an additional release associated with 25 percent of the core reaching $2000 \mathrm{~K}$. The boiling points (Table 4-1) were examined to estimate the fractions of the fission products that would be volatilized at $2000 \mathrm{~K}$. Since the boiling points of noble gases, iodine, cesium and tritium are all below $1000 \mathrm{~K}$, it was assumed that 100 percent of these fission products contained within the portion that reaches $2000 \mathrm{~K}$ are released. Equation [4-1] is used to calculate the release fractions of the NG, $\mathrm{I}, \mathrm{Cs}$ and ${ }^{3} \mathrm{H}$ element groups for a melt scenario which includes a recriticality event. 
$\mathrm{RF}_{\text {recriticality }}=\mathrm{RF}_{\text {normal melt }}+\left(1-\mathrm{RF}_{\text {normal melt }}\right) * 0.25$

The $\mathrm{Te}, \mathrm{Sr}$ and $\mathrm{Ba}$ element groups have boiling points that are above $1000 \mathrm{~K}$ but less than $2000 \mathrm{~K}$. Since the maximum temperature due to a recriticality event is $2000 \mathrm{~K}$ and the portion of the core involved in the recriticality is at that temperature for a very short period of time before it drops to the relocation temperature $(950 \mathrm{~K})$, it is believed that a only a fraction of the $\mathrm{Te}, \mathrm{Sr}$ and $\mathrm{Ba}$ (which is present in the portion of the core involved in the recriticality) would be released. Release fractions for these elements were thus set based on engineering judgement. The $\mathrm{Ru}, \mathrm{La}$ and Ce element groups have boiling points much higher than $2000 \mathrm{~K}$, therefore, none of these species are released during a recriticality event.

The release fractions for a power excursion were calculated using the same method used to calculate the release fractions due to a recriticality event except that only 10 percent of the core is involved in the power excursion. Thus, 10 percent of the core reaches $2000 \mathrm{~K}$ for a short period of time and then cools to the relocation temperature. Equation [4-2] is used to calculate the release fractions of the NG, I, Cs and ${ }^{3} \mathrm{H}$ element groups for a power excursion.

$R F_{\text {power excursion }}=R F_{\text {normal melt }}+\left(1-R F_{\text {normal melt }}\right) * 0.10$

For consistency, the release fractions of the $\mathrm{Te}, \mathrm{Sr}$ and $\mathrm{Ba}$ element groups for a power excursion were estimated by multiplying the release fractions estimated for a recriticality event by the ratio $\frac{10}{25}$. The $\mathrm{Ru}, \mathrm{La}$ and $\mathrm{Ce}$ element groups have boiling points much higher than $2000 \mathrm{~K}$, therefore, it is improbable that any of these species would be released during a power
excursion. 
WSRC-RP-92-973

Table 4-2. Release Fractions During Fuel Melt

Non-Energetic

\begin{tabular}{lccc} 
Group Name & Melt & Recriticality & Power Excursion \\
\hline & & & \\
Noble Gas & 0.80 & 0.85 & 0.82 \\
Iodine & 0.15 & 0.36 & 0.24 \\
Cesium & 0.05 & 0.29 & 0.15 \\
Tellurium & 0.00 & 0.2 & 0.08 \\
Strontium & 0.00 & 0.05 & 0.02 \\
Ruthenium & 0.00 & 0.00 & 0.00 \\
Lanthanum & 0.00 & 0.00 & 0.00 \\
Cerium & 0.00 & 0.00 & 0.00 \\
Barium & 0.00 & 0.03 & 0.01 \\
Tritium & 0.80 & 0.85 & 0.82 \\
& & & \\
\hline
\end{tabular}

\subsubsection{Heat up of the Core on the Vessel Bottom}

The input parameter which gives the release fraction from fuel during fuel heat up of the core is erf. This parameter has a value for each of the ten element groups in three possible scenarios : 1) the core debris flows through the reactor vessel effluent muffs and attains temperatures sufficient to melt the stainless steel pipe walls, 2) the debris structurally fails the bottom shield, and 3) a steam explosion fails the bottom shield or effluent piping. In the first case, the core debris is assumed to reach temperatures greater than $1700 \mathrm{~K}$ before failing the piping or being stabilized (i.e., eventually solidifying) within the pipe. In the second case, the core debris is assumed to reach a maximum temperature of $1400 \mathrm{~K}$ (based on the structural evaluation) before the bottom shield fails. In the third case, the debris is assumed to relocate at $1000 \mathrm{~K}$, and a steam explosion is then assumed to fail either the bottom shield or effluent piping. The steam explosion is also assumed to terminate the early phase releases. MELCOR/SR calculations were performed to approximately simulate the three scenarios outlined above. The results from these calculations are shown in Table 4-3. 
WSRC-RP-92-973

Table 4-3. Release Fractions During Core Debris Heat Up

\begin{tabular}{lccc} 
Group Name & $\begin{array}{c}\text { Core Debris at } \\
\mathbf{1 7 0 0 ~ K}\end{array}$ & $\begin{array}{c}\text { Core Debris at } \\
\mathbf{1 4 0 0 ~ K}\end{array}$ & $\begin{array}{c}\text { Core Debris at } \\
\mathbf{1 0 0 0} \mathbf{K}\end{array}$ \\
\hline Noble Gas & & & \\
Iodine & 1.00 & 1.00 & 1.00 \\
Cesium & 0.99 & 0.99 & 0.90 \\
Tellurium & 0.99 & 0.99 & 0.50 \\
Strontium & 0.75 & 0.7 & 0.00 \\
Ruthenium & 0.10 & 0.00 & 0.00 \\
Lanthanum & 0.00 & 0.00 & 0.00 \\
Cerium & 0.00 & 0.00 & 0.00 \\
Barium & 0.00 & 0.00 & 0.00 \\
Tritium & 0.05 & 0.00 & 0.00 \\
& 1.00 & 1.00 & 1.00 \\
\hline
\end{tabular}

\subsubsection{Release Fractions During Steam Explosions}

The input parameter which gives the release fraction from fuel during a steam explosion is rfstmx. This parameter has a value for each of the ten element groups. Steam explosion experiments available at the time of the PRAST development indicated that particle sizes generated during a steam explosion were typically tens of micrometers or greater. Given these particle sizes, it was deemed unlikely that significant radionuclide release would occur during a steam explosion. Consequently, the release fractions were all set to 0.0 .

Since the time that the PRAST parameters were established, steam explosion experiments with aluminum melts have been performed at SNL. Experimental conditions during the SNL tests were non-protypic of most scenarios considered in the Level 2 PRA. Therefore, applicability of experimental results to conditions forming the basis for PRAST input parameters are uncertain. These experiments have shown that steam explosions with aluminum melts can be augmented by an extremely vigorous exothermic reaction between the alumirum and the water (liquid or vapor). The rapid thermal and mechanical energy generation that accompanies these interactions leads to higher temperatures and smaller particle sizes than observed in prior experiments. If a similar steam 
explosion were to occur during a reactor accident, there may be significant release from the core debris participating in the interaction.

\subsubsection{Release Fractions During Molten Core Concrete Interactions}

The input parameter which gives the release fraction from fuel during core concrete interactions is $l r f$. This parameter has a value for each of the ten element groups. The quantification of this parameter is based on the results of the SRL-1 experiment [5]. The interpretation of these results for application to the PRAST calculations for the SRS PRA is given in Table 4-4.

Table 4-4. Release Fractions During Core-Concrete Interactions

Group Name Release Fraction

$\begin{array}{lc}\text { Noble Gas } & 1.00 \\ \text { Iodine } & 0.99 \\ \text { Cesium } & 0.99 \\ \text { Tellurium } & 0.99 \\ \text { Strontium } & 2.4 \mathrm{E}-02 \\ \text { Ruthenium } & 2.2 \mathrm{E}-04 \\ \text { Lanthanum } & 1.3 \mathrm{E}-04 \\ \text { Cerium } & 6.8 \mathrm{E}-05 \\ \text { Barium } & 8.1 \mathrm{E}-03 \\ \text { Tritium } & 1.00\end{array}$

\subsubsection{Release Fractions From Structural Surfaces}

The release fractions from structural surfaces are based on MELCOR/SR calculations, experimental data and engineering judgement which considered previous analyses of this type. The structural surfaces analyzed for fission product revolatilization are the primary system structures and the confinement filters. Revolatilization from confinement structures such as floors and walls was assumed to be neglible due to their relatively low temperatures. 


\subsubsection{Release Fractions From Primary System Surfaces}

The PRAST input parameter which gives the fraction of fission products that are revolatilized from vessel surfaces after primary system failure is vrf. A value has been assigned for each of the ten element groups for either a high release or a moderate release.

Revolatilization of radionuclides initially trapped on primary system surfaces occurs when the surfaces subsequently increase in temperature. Heating of the surfaces may be due to fission product decay or to the passage of hot gases. The rate of revolatilization depends also on the magnitude of the gas flow past the surfaces.

MELCOR/SR calculations were performed to estimate the amount of radionuclides that would revolatilize. Due to model uncertainties and limitations, it was felt that these calculations were not sufficiently reliable to provide the required values for vrf. As an alternative, revolatilization fractions used in the NUREG-1150 analysis of commercial power plants were used as the basis [6].

Revolatilization, like retention, can be expected to behave in a similar fashion for both SRS and LWR reactors. Phenomenological differences between the two reactor technologies have been taken into account by qualitatively defining the differences and applying engineering judgement to evaluate the impact on revolatilization. Steam flow rates in the reactor and the potential for cooling of primary structures are the two factors expected to most significantly contribute to differences in the level of revolatilization between the two reactor designs. A comparison of the two reactor types and an evaluation of potential revolatilization are summarized below.

The principal effect of high steam flow is to continuously purge the primary system atmosphere. This tends to reduce the fission product concentration in the atmosphere and leads to higher concentration gradients between the gas and surface deposits of fission products. Higher concentration gradients promote mass transfer and increase revolatilization.

Gas flow rates through the SRS primary system following vessel breach are expected to be higher than for an LWR. In K Reactor, the vessel is open to the confinement at the top through the stand pipes and the pressure relief system. If the bottom of the vessel is breached during core melting and relocation, a passage for air flow through the vessel may be established.

Cooling of primary system structures reduces the surface temperature and, therefore, reduces the level of revolatilization. K Reactor has actively cooled top, bottom, and biological shields that are independent of the primary cooling water. Therefore, $\mathrm{K}$ Reactor may have relatively cool primary system surfaces during the accident. This could lead to dramatically lower revolatilization than assumed for the commercial LWRs in NUREG-1150 [6]. It should be noted, however, that the operability 
of the shield cooling systems during severe accidents has not been investigated. Furthermore, the ability of the shield cooling systems to cool surfaces with deposited fission products has not been demonstrated. Calculations have shown [7], for instance, that the design of the bottom shield zenders the cooling system ineffective at cooling the vessel bottom if fuel debris has been deposited on it. In light of these considerations, the accident progression analysis does not take credit for the shield cooling systems. Revolatilization from vessel surfaces is thus expected to be significant and fairly rapid.

Under most conditions, the heat exchanger surfaces are expected to remain cool during the accident (the exception being cases in which the secondary cooling system has been significantly dami ged). Consequently, little or no revolatilization of fission products from heat exchanger surfaces is expected for plant damage states where secondary coolir. . water flow is available.

In summary, high steam flow ratco and the relative lack of primary system cooling will favor revolatilization in $\mathrm{K}$ Reactor relative to commercial reactors. These effects are currently believed to lead to higher revolatilization than in commercial reactors accidents. Consequently, the values for urf are higher than the values used in NUREG-1150.

The revolatilization fractions used in NUREG-1150 were based on expert elicitation. There was considerable variation among the revolatilization fractions assigned by the experts. In general, the experts assigned mean values that ranged from app oximately 0.0 to nearly 0.4 . When these ralues were averaged together to determine the final distributions, the mean values for the six cases that they were asked to consider ranged from 0.0 to approximately 0.2 The revolatilization fractions were further broken down by radionuclide. Under most conditions, iodine was approximately twice as likely to be released as cesium, and the release of tellurium and other radionuclides was negligible. Tellurium was assumed to be largely chemisorpted on primary system surfaces. Other fission products, and their oxides, have very low volatility.

The interpretation of the NUREG-1150 analysis information on fission product revolalilization for application to PRAST is given in Table 4-5. 
WSRC-RP-92-973

Table 4-5. Revolatilization Fractions of Fission Products from Primary System Surfaces

\begin{tabular}{lcc} 
Group Name & High Revolatilization & Moderate Revolatilization \\
\hline & & \\
Noble Gas & 0.00 & 0.00 \\
Iodine & 0.60 & 0.30 \\
Cesium & 0.30 & 0.15 \\
Tellurium & 0.05 & 0.02 \\
Strontium & 0.00 & 0.00 \\
Ruthenium & 0.00 & 0.00 \\
Lanthanum & 0.00 & 0.00 \\
Cerium & 0.00 & 0.00 \\
Barium & 0.00 & 0.00 \\
Tritium & 0.00 & 0.00 \\
\end{tabular}

\subsubsection{Release Fractions From Filters}

The PRAST input parameter which give: the fraction of fission products that are released from the filters is ltfrf. It has a value for each of the ten element groups for either a filter burn or desorption.

This PRAST parameter specifies the radionuclide release fractions that would accompany later filter burning or late iodine desorption. No relevant data were available. Initial calculations performed assuming complete release yielded overly conservative results. Engineering judgement was then applied considering the potential dissolution of radionuclides in the

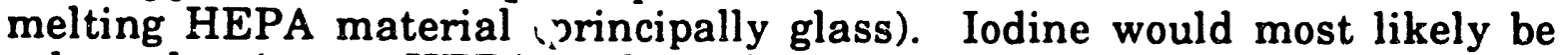
released prior to HEPA i. elting but other species were judged to be substantially retained. Filter burning was thus assumed to release $100 \%$ of the trapped iodine, $80 \%$ of the trapped cesium (also fairly volatile in the hydroxide form), $50 \%$ of the tellurium and $20 \%$ of the remaining radionuclides. Iodine desorption from charcoal was assumed to release $90 \%$ of the trapped iodine based on data relevant to the K Reactor charcoal material. These values are summarized in Table 4-6. 
Table 4-6. Late Filter Release Fractions

\begin{tabular}{lcc} 
Group Name & Filter Burn & Filter Desorption \\
\hline & & \\
Noble Gas & 1.00 & 1.00 \\
Iodine & 1.00 & 0.90 \\
Cesium & 0.80 & 0.00 \\
Tellurium & 0.50 & 0.00 \\
Strontium & 0.20 & 0.00 \\
Ruthenium & 0.20 & 0.00 \\
Lanthanum & 0.20 & 0.00 \\
Cerium & 0.20 & 0.00 \\
Barium & 0.20 & 0.00 \\
Tritium & 1.00 & 1.00 \\
\hline
\end{tabular}

\subsubsection{Release Fractions From Contaminated Water}

The release fractions from contaminated water are based on experimental data and engineering judgement which considered previous analyses of this type. The bodies of water analyzed for fission product revolatilization were the primary system water, the water in the confinement, and the water outside the confinement in the contaminated water storage tank.

\subsubsection{Release Fractions From Primary System Water}

No PRAST input parameter exists for the release fraction of fission products that are trapped in primary system water. PRAST is coded so that a primary system boil off will result in the release of 100 percent of the fission products trapped in the water.

\subsubsection{Release Fractions From Confinement Water}

No PRAST input parameter exists for the release fraction of fission products that are trapped in confinement system water. PRAST is coded so that a boil off of the water in the pump room will result in the release of 100 percent of the fission products trapped in the water. 


\subsubsection{Release Fractions From Water Outside Confinement}

The PRAST input parameter which gives the fraction of fission products that are released from the water outside confinement is vlrf. It has a value for each of the ten element groups.

During a severe accident, contaminated water can be pumped from the process room and pump room floors to the contaminated water storage tank or the $\mathbf{5 0}$ million gallon retention basin. PRAST has been coded to assume, after the fourth time period, all water in the confinement is transferred outside the confinement. The vlrf parameter specifies the fraction of fission products trapped in below grade water that is released to the below grade atmosphere (one value for each of the ten element groups). No revolatilization from the CWST or the 50 million gallon retention basin of any fission products other than iodine has been assumed, therefore, this discussion will focus on the release of iodine,

Revolatilization of trapped iodine depends on the $\mathrm{pH}$ of the water, the magnitude of the surrounding radiation field, the rate of gas bubbling through the water, and the extent to which the water evaporates. At high $\mathrm{pH}$ values, iodine reacts chemically in the water to form more nonvolatile species. Iodine can also be converted to nonvolatile forms in the presence of radiation. Gas bubbling increases iodine release by increasing the surface area available for release. The effects of $\mathrm{pH}$, radiation, and gas bubbling have been verified in experiments by Beahm [8] and others. In general these experiments have shown that no more than one percent of the iodine will be released from the water pool as long as the pool remains basic ( $\mathrm{pH}>$ 7). During a severe accident, the water pool is expected to become increasingly more basic as the accident proceeds due to formation of various hydroxides (e.g., $\mathrm{CsOH}$ ) and the addition of basic oxides such as $\mathrm{Na}_{2} \mathrm{O}$ and $\mathrm{K}_{2} \mathrm{O}$ that are released during core-concrete interactions.

Evaporation is thought to favor release of iodine. In one of the few experiments conducted to examine iodine release during water evaporation, Wisbey [9] completely evaporated a solution with dissolved CsI and a $\mathrm{pH}$ of 9 . In this experiment, approximately 22 percent of the iodine was converted to volatile form.

Based on the above discussion, iodine revolatilization fractions of from 1 to about 20 percent appear justified. Because substantial evaporation of contaminated water is anticipated during the late phases of an SRS severe accident, a value in the upper portion of this range was assigned. The values of vlrf are summarized in Table 4-7. 
WSRC-RP-92-973

Table 4-7. Very Late Contaminated Water Revolatilization Release Fractions

Group Name

Revolatilization Release Fraction

Noble Gas

0.00

Iodine

0.15

Cesium

0.00

Tellurium

0.00

Strontium

0.00

Ruthenium

0.00

Lanthanum

0.00

Cerium

0.00

Barium

0.00

Tritium

0.00 


\subsection{Decontamination Factors}

PRAST requires the decontamination factors due to structural surfaces and overlying contaminated water as input. In a postulated severe accident, fission products could plate out on structural surfaces or be trapped in a pool of overlying water. These subjects, as they relate to PRAST, are discussed in the following sections.

\subsubsection{Decontamination Factors of Overlying Water}

The decontamination factors (DFs) due to overlying water are based on experimental data and engineering judgement which considered the previous analyses of this type.

\subsubsection{Decontamination Factors of Primary System Water}

The PRAST input parameter which gives the DF of primary system water for fission products that are released in-vessel is $d f i v w$. It has a value for each of the ten element groups. Since noble gases are not affected by an overlying pool, their DFs are set 1.0. The remainder of this discussion focus on the DFs for iodine and aerosols. In this discussion, the term aerosols refers to the $\mathrm{Cs}, \mathrm{Te}, \mathrm{Sr}, \mathrm{Ru}, \mathrm{La}, \mathrm{Ce}$, and $\mathrm{Ba}$ element groups.

Iodine and aerosols that are bubbled through an overlying water pool can be trapped by the pool, and thereby prevented from escaping from the reactor vessel. The removal mechanisms are the same as those that govern performance of suppression pools in Boiling Water Reactors (BWRs). Consequently, analytical models and experimental results for suppressicn pool behavior were used to determine the appropriate values for dfivw.

Aerosol removal occurs by several different mechanisms, including: sedimentation, impaction, diffusion, and diffusiophoresis (i.e., condensation driven impaction). Sedimentation occurs when aerosol particles settle out of vapor phase and onto the bubble surface. Sedimentation is more efficient for larger particles. Impaction occurs when the aerosol particles are unable to stay within the flow of the circulating gas in the bubble, and subsequently impact the bubble surface. As might be expected, impaction is much more significant for larger aerosol particles. Particle diffusion occurs due to momentum exchange with surrounding gas molecules. Diffusion is more effective for smaller aerosol particles. Condensation can occur when the steam in the bubbles is supersaturated relative to conditions at the bubble surface (e.g., in a subcooled pool). The condensing steam carries with it aerosol particles, which are subsequently trapped by the bubble surface. This process is diffusiophoresis.

The magnitude of the decontamination factor depends greatly on the depth and temperature of the water pool, the size of the rising bubbles, the aerosol particle size distribution, and the steam content of the bubbles. Given the 
uncertainty associated with many of these parameters, there is significant uncertainty in the values that should be assigned to the water pool DFs.

Past experiments to investigate BWR suppression pool scrubbing [21] have indicated that the water pool DF is likely to fall in the range from 10 to 1000 for the pool depths, and particle sizes (0.2 to 1.0 micrometers) likely to be present in severe accidents postulated for K Reactor. Somewhat smaller values are predicted by the pool scrubbing models in MELCOR. However, it is currently felt that the models in MELCOR under predict measured water pool DFs by factors of 5 to 10 . For this reason, the DF values used in PRAST were based on the experiment data rather than on code calculations.

For cases with no water in the vessel, the DFs were assumed to be 1.0. If the vessel was full of water, DFs of 50.0 were assumed. This is the value used in the Modular Accident Analysis Program (MAAP) for scrubbing in pools when the initial bubble size is very large $(-0.5 \mathrm{~m})$. It should be noted that differences between DFs greater than 10 are probably not significant from the standpoint of the overall risk profile since the consequent radionuclide releases would be very small.

Table 4-8. Decontamination Factors of Primary System Water

\begin{tabular}{lcc} 
Group Name & Water in Vessel & No Water in Vessel \\
\hline & & \\
Noble Gas & 1.0 & 1.0 \\
Iodine & 50.0 & 1.0 \\
Cesium & 50.0 & 1.0 \\
Tellurium & 50.0 & 1.0 \\
Strontium & 50.0 & 1.0 \\
Ruthenium & 50.0 & 1.0 \\
Lanthanum & 50.0 & 1.0 \\
Cerium & 50.0 & 1.0 \\
Barium & 50.0 & 1.0 \\
Tritium & 1.0 & 1.0 \\
\hline
\end{tabular}


WSRC-RP-92-973

\subsubsection{Decontamination Factors of Water Overlying MCCI}

The PRAST input parameter which gives the DF of primary system water for fission products that are released in-vessel is $d f c c i$. It has a value for each of the ten element groups in five possible states. Since noble gases are not affected by an overlying pool, their DFs are set 1.0 . The remainder of this discussion focus on the DFs for iodine and aerosols.

The mechanisms governing aerosol removal by overlying water pools are the same as those governing aerosol removal by suppression pools in Boiling Water Reactors. These mechanisms were discussed previously in Section 4.2.1.2.

The decontamination factors for water pools overlying an ongoing CCI are expected to be smaller than the DFs associated with in-vessel phenomena. This is true for two primary reasons. First, the bubbles rising in the exvessel water pool will have a higher concentration of noncondensable gases than for bubbles generated in-vessel. The higher concentration of noncondensible gas will lead to reduced condensation onto the bubble surface. Second, the ex-vessel bubbles are likely to be larger than the invessel bubbles (due, in part to the greater amount of noncondensable gas). Larger bubbles are known to be less effective at trapping aerosols. For these reasons, the values of ccidf are smaller than those defined for the dfivw.

The values of ccidf for iodine and aerosols are identical for a given depth of overlying water. Five states were considered for ccidf in PRAST. These states varied only in the depth of the water pool on the pump room floor. For water pools greater than 84 inches deep (referred to as flooded), the DFs for iodine and aerosols were assumed to be 10.0 . For water pools that were between 8 and 84 inches deep (referred to as submerged), the DFs for iodine and aerosols were assumed to be 5.0. For water pools less than 8 inches deep (referred to as dry), the DFs for iodine and aerosols were assumed to be 2.0. Finally, in states with no water on the pump room floor, the DFs were assumed to be 1.0.

It should be noted that the values of ccidf used in PRAST are consistent with the limited database on water pool scrubbing of CCI aerosols and predictions of the pool scrubbing model in VANESA [10]. In the SWISS experiments that were performed at SNL [11], highly sub-cooled water pools approximately 40 to $50 \mathrm{~cm}$ deep were found to produce DFs on the order of 9 to 30 . It should be noted, however, that the DFs in these experiments may have been artificially high due to the formation of a thick overlying crust on the steel melt, which may have contributed to the observed aerosol removal. Crust formation would not be expected for the lower melting point core materials in $\mathrm{K}$ Reactor. Table 4-9 summarizes the values of ccidf used by
PRAST. 
Table 4-9. Decontamination Factors of Water Overlying MCCI

\begin{tabular}{lcccc} 
Group Name & No water & Dry & Submerged & Flooded \\
\hline Noble Gas & & & & \\
Iodine & 1.0 & 1.0 & 1.0 & 1.0 \\
Cesium & 1.0 & 2.0 & 5.0 & 10.0 \\
Tellurium & 1.0 & 2.0 & 5.0 & 10.0 \\
Strontium & 1.0 & 2.0 & 5.0 & 10.0 \\
Ruthenium & 1.0 & 2.0 & 5.0 & 10.0 \\
Lanthanum & 1.0 & 2.0 & 5.0 & 10.0 \\
Cerium & 1.0 & 2.0 & 5.0 & 10.0 \\
Barium & 1.0 & 2.0 & 5.0 & 10.0 \\
Tritium & 1.0 & 2.0 & 5.0 & 10.0 \\
& 1.0 & 1.0 & 1.0 & 1.0 \\
\hline
\end{tabular}

\subsubsection{Decontamination Factors of Structures}

The decontamination factors due to primary system and confinement structures are based on MELCOR/SR calculations, experimental data and engineering judgement which considered the previous analyses of this type. The structural surfaces analyzed for fission product decontamination are the primary system structures and the confinement walls, floors, and ducting.

\subsubsection{Decontamination Factors of Primary System Structures}

The PRAST input parameter which gives the DF of primary system structures for fission products that are released in-vessel is dfiv. It has a value for each of the ten element groups in three possible states. Since airborne noble gases and tritium are not decontaminated by primary system structures, their DFs are set 1.0 . The remainder of this discussion will focus on the DFs for iodine and aerosols.

In the absence of an overlying water pool, aerosols and iodine will still be retained to some extent within the primary system. Aerosols can become deposited by several processes including: sedimentation, impaction, diffusiophoresis, and thermophoresis. Condensation of steam can also lead to radionuclide deposition. Steam condensation is particularly important for deposition of iodine and cesium. Once deposited, chemisorption can occur to further bind radionuclides to the surfaces. Under most conditions, 
gravitational settling is the dominant retention mechanism. Impaction can play a role if gas velocities are significant.

The following factors are important in determining the extent of retention within the primary system: (1) gas flow rates through the primary system, (2) geometric complexity of primary system structures, (3) extent of natural circulation within the primary system, (4) the size distribution of aerosol particles, (5) the fission product density or concentration, and (6) chemical reactions between radionuclides and primary system materials. The effects of these phenomena are discussed below.

The principal effect of high gas flow rates is to reduce the residence time of fission products in the primary system, thereby reducing retention. In postulated severe SRS reactor accidents, the vessel is either completely dry or contains a significant quantity of sub-cooled water. Either case leads to low steaming rates. If the vessel has been dried due to debris heating, the water is largely evaporated by the time the rate of fission product release becomes large. If the vessel contains sub-cooled water, the steam generated by film boiling at the interface with the debris would be condensed in the water. Since steam generation represents the principal source for gas flow, residence times for fission products in the primary system are expected to be long.

The principal effects of a complex geometric configuration are to provide a large surface area onto which fission products can plate out, and to provide complex flow paths which reduce direct leakage from the primary system. $\mathrm{K}$ Reactor has relatively cool structures in the upper portion of the vessel and in the primary system loops since the top shield and heat exchangers both contain cooling water. The presence of these cool structures enhances deposition by direct condensation of fission products from the vapor phase. Diffusiophoresis is also enhanced.

Natural circulation generally tends to enhance fission product retention by producing circulatory flows between hot regions (where fission products are released) to cooler regions where deposition occurs. The circulatory flows also increase the surface area to which the fission products are exposed.

Aerosol size is an important consideration since larger particles are more likely to settle out of the vapor phase or impact structures. Aerosol sizes will be smaller in $\mathrm{K}$ Reactor than in a commercial reactor with zircaloyclad, oxide fuel. There is no evidence to suggest that structural aerosols will form during the melting of an SRS core. In the absence of structural aerosols, fission product vapors will tend to condense on homogeneously nucleated sites. This process leads to small aerosols $(0.2$ to 0.5 micrometers aerodynamic mass-mean diameter) which settle very slowly, and tend to be carried along by the flowing vapor. These small aerosols are, however, more susceptible to diffusiophoretic depusitition, which may be important in $\mathrm{K}$ Reactor (see discussion above). It must also be noted that scrubbing of the gas flow by a water pool will alter the size distribution of retained aerosols. 
If the aerosols first pass through a water pool, the fraction reaching the primary system atmosphere that would be deposited will be reduced due to the removal of larger aerosols by the water.

The aerosol density is an important consideration since collisions between particles can lead to agglomeration. The agglomerated particles have a larger effective size, and consequently settle out at much faster rate. Thus higher densities lead to increased retention. Again, scrubbing by a water pool prior to accumulating in the primary system atmosphere will reduce the aerosol density and thus reduce agglomeration.

Chemical reactions with steel structures within the primary system can be important under some conditions. This is particularly true for Cs, I, and Te. Gaseous forms of iodine can react with steel surfaces to form nickel iodide, while $\mathrm{CsOH}$ has been observed to react with stainless steel to form stable compounds such as cesium silicates. Similarly, tellurium has an affinity for metals in the steel and can form stable compounds such as nickel telluride. Formation of these stable compounds increases retention within the primary system.

Retention within the primary system has been calculated by MELCOR/SR. However, the deposition models and aerosol behavior models within MELCOR have been greatly simplified, and are unlikely to provide reliable results. For this reason, the decision was made to base retention fractions on engineering judgement. This judgement relied, in part, on the results used for NUREG-1150 analysis of the Peach Bottom nuclear power plant [6]. The MELCOR predictions were also considered.

The values for primary system retention used in NUREG-1150 were determined using expert elicitation. Three experts in fission product behavior were polled to determine probability distributions for in-vessel fission product retention for several BWR and PWR accident scenarios. The median DFs determined by averaging the distributions provided by the experts ranged from 2 to 30; however, for the low pressure cases (which are most similar to SRS conditions), the DFs were in the range of from 2 to 4 . When determining the values to be used in the APET, consideration was given to the simpler geometry of the SRS vessel and primary system. Commercial power reactors have considerable amounts of vessel internals (e.g., control rod housings, core support structure, downcommer regions, steam separators, and dryers). In cases where core debris blocks the effluent muffs or piping that leads to the heat exchangers, the $\mathrm{K}$ Reactor primary system is essentially a single, unobstructed volume (assuming the fuel assemblies, control rod septifoils, and safety rod structures have melted). It was also felt that the aerosols generated during melting and heatup of the core debris would be smaller than aerosols generated in LWR accidents due to the makeup of the fuel. Smaller aerosols are transported more readily by the flowing gas, and, as a result, undergo less sedimentation and impaction. Given these conditions, it was felt that the appropriate DFs for the $\mathrm{K}$ Reactor would be smaller than those used in 
NUREG-1150. The primary system DFs used in PRAST therefore ranged from 1.0 to 2.0 .

Decontamination factors of 1.0 were assigned to cases in which the vessel was full or nearly full, and to cases in which a steam explosion failed the bottom of the vessel during or after core melting.

For cases with energetic expulsion of the vessel water, the DF for iodine was assumed to be 1.1 while the DF for aerosols was assumed to be 1.2. The DFs are assumed to be small because of the high gas flows that would occur under these conditions. The iodine DF was assumed to be smaller because the mechanisms for iodine retention (condensation and diffusiophoresis) are expected to be even less efficient under these circumstances.

In dry vessel cases without energetic expulsion of the vessel water, gas flows through the primary system would be relatively low. Consequently, the residence time for aerosols and iodine in the primary system would be sufficiently long to allow more extensive retention. In these cases, the DF for iodine was assumed to be 1.5, while the DF for aerosols was assumed to be 2.0. The aerosol value is consistent with the MELCOR/SR calculations. The iodine DF was somewhat arbitrarily reduced to reflect the fact that the high temperatures of primary system surfaces predicted by MELCOR would limit iodine retention (as CsI as well as $\mathrm{I}_{2}$ ), even in the short term. Cesium aerosol may be retained due to chemisorption of the hydroxide compound. Table 4-10 summarizes the values of $d f i v$ used by PRAST. 
WSRC-RP-92-973

Table 4-10. Decontamination Factors of Primary System Structures

\begin{tabular}{lllc} 
Group Name & Water in Vessel & Dry & $\begin{array}{c}\text { Water } \\
\text { Energetically } \\
\text { Expelled }\end{array}$ \\
\hline Noble Gas & 1.0 & 1.0 & \\
Iodine & 1.0 & 1.5 & 1.0 \\
Cesium & 1.0 & 2.0 & 1.1 \\
Tellurium & 1.0 & 2.0 & 1.2 \\
Strontium & 1.0 & 2.0 & 1.2 \\
Ruthenium & 1.0 & 2.0 & 1.2 \\
Lanthanum & 1.0 & 2.0 & 1.2 \\
Cerium & 1.0 & 2.0 & 1.2 \\
Barium & 1.0 & 2.0 & 1.2 \\
Tritium & 1.0 & 1.0 & 1.2 \\
& & & 1.0 \\
\hline
\end{tabular}

\subsubsection{Decontamination Factors of Confinement Structures}

The PRAST input parameters which give the DF of confinement structures for fission products are ecdf, ecdfmn and lcdf. The parameter ecdf describes the decontamination factors of the above grade confinement, while ecdfmn describes the minimum decontamination factors of the above grade confinement when the process room sprays are operating. Both parameters have a value for each of the ten element groups in six possible confinement states. The six confinement states examined for the above grade confinement DFs were : 1) total confinement building failure (due to a seismic event or a catastrophic vessel failure), 2) confinement building breach with closure of the main exhaust dampers, 3 ) confinement building breach with the main exhaust dampers open, 4) airborne activity confinement system (AACS) operating normally, 5) AACS fan failure, and 6) closure of the main exhaust dampers with no building breach.

MELCOR/SR calculations were used to provide the values for ecdf for iodine and aerosols. As part of the evaluation of confinement system performance, a series of MELCOR/SR calculations was performed to examine confinement response under a range of accident conditions. The results from these calculations were matched to the ecdf confinement states to assign the parameter values. The details of the confinement response 
calculations are provided in [12]. Table 4-11 summarizes the values calculated for ecdf.

CONTAIN calculations [13] were used to provide the values for ecdfmn for iodine and aerosols. The DFs for aerosol removal due to the combined action of sprays and confinement surfaces were calculated to range from 1.0 to 100.0 , with most values in the range from 1.2 to 2.5 . In general, the higher the residence time, the larger the calculated DF. Table 4-12 summarizes the values calculated for ecdfmn.

\section{Table 4-11. Decontamination Factors of Above Grade Confinement Structures Without Sprays}

\begin{tabular}{lllllll}
$\begin{array}{l}\text { Group } \\
\text { Name }\end{array}$ & $\begin{array}{c}\text { Building } \\
\text { Failure }\end{array}$ & $\begin{array}{c}\text { Building } \\
\text { Breach } \\
\text { with } \\
\text { Dampers } \\
\text { Closed }\end{array}$ & $\begin{array}{c}\text { Building } \\
\text { Breach } \\
\text { with } \\
\text { Dampers } \\
\text { Open }\end{array}$ & $\begin{array}{c}\text { AACS } \\
\text { Operating }\end{array}$ & Fan Failure & $\begin{array}{c}\text { Damper } \\
\text { Closure }\end{array}$ \\
\hline Noble Gas & 1.0 & 1.0 & 1.0 & 1.0 & 1.0 & 1.0 \\
Iodine & 1.0 & 1.0 & 1.0 & 1.0 & 1.0 & 1.0 \\
Cesium & 1.0 & 1.2 & 1.2 & 1.0 & 1.4 & 2.2 \\
Tellurium & 1.0 & 1.2 & 1.2 & 1.0 & 1.4 & 2.2 \\
Strontium & 1.0 & 1.2 & 1.2 & 1.0 & 1.4 & 2.2 \\
Ruthenium & 1.0 & 1.2 & 1.2 & 1.0 & 1.4 & 2.2 \\
Lanthanum & 1.0 & 1.2 & 1.2 & 1.0 & 1.4 & 2.2 \\
Cerium & 1.0 & 1.2 & 1.2 & 1.0 & 1.4 & 2.2 \\
Barium & 1.0 & 1.2 & 1.2 & 1.0 & 1.4 & 2.2 \\
Tritium & 1.0 & 1.0 & 1.0 & 1.0 & 1.0 & 1.0 \\
& & & & & & \\
\hline
\end{tabular}


Table 4-12. Decontamination Factors of Above Grade Confinement Structures With Sprays

\begin{tabular}{lcccccc}
$\begin{array}{l}\text { Group } \\
\text { Name }\end{array}$ & $\begin{array}{l}\text { Building } \\
\text { Failure }\end{array}$ & $\begin{array}{c}\text { Building } \\
\text { Broach } \\
\text { with } \\
\text { Dampers } \\
\text { Cloaged }\end{array}$ & $\begin{array}{c}\text { Building } \\
\text { Breach } \\
\text { with } \\
\text { Dampers } \\
\text { Open }\end{array}$ & $\begin{array}{c}\text { AACS } \\
\text { Operating }\end{array}$ & Fan Failure & $\begin{array}{c}\text { Damper } \\
\text { Closure }\end{array}$ \\
\hline Noble Gas & 1.0 & 1.0 & 1.0 & 1.0 & 1.0 & 1.0 \\
Iodine & 1.0 & 2.0 & 1.4 & 1.3 & 2.5 & 100.0 \\
Cesium & 1.0 & 2.0 & 1.3 & 1.2 & 2.0 & 10.0 \\
Tellurium & 1.0 & 2.0 & 1.3 & 1.2 & 2.0 & 10.0 \\
Strontium & 1.0 & 2.0 & 1.3 & 1.2 & 2.0 & 10.0 \\
Ruthenium & 1.0 & 2.0 & 1.3 & 1.2 & 2.0 & 10.0 \\
Lanthanum & 1.0 & 2.0 & 1.3 & 1.2 & 2.0 & 10.0 \\
Cerium & 1.0 & 2.0 & 1.3 & 1.2 & 2.0 & 10.0 \\
Barium & 1.0 & 2.0 & 1.3 & 1.2 & 2.0 & 10.0 \\
Tritium & 1.0 & 1.0 & 1.0 & 1.0 & 1.0 & 1.0 \\
& & & & & & \\
\hline
\end{tabular}

The parameter lcdf describes the decontamination factors of the below grade confinement. It has a value for each of the ten element groups in three possible confinement retention levels. The three retention levels are high, moderate and none. MELCOR/SR calculations were used to provide the values for $l c d f$ for iodine and aerosols. As part of the evaluation of confinement system performance, a series of MELCOR/SR calculations was performed to examine confinement response under a range of accident conditions. The results from these calculations were analyzed to determine the range of below grade confinement retention. The details of the confinement response calculations are provided in [12]. Table 4-13 summarizes the values calculated for $l c d f$. 
WSRC-RP-92-973

Table 4-13. Decontamination Below Grade Confinement Structures

Moderate

\begin{tabular}{lccc} 
Group Name & High Retention & Retention & No Retention \\
\hline & & & \\
Noble Gas & 1.0 & 1.0 & 1.0 \\
Iodine & 1.5 & 1.5 & 1.1 \\
Cesium & 2.0 & 2.0 & 1.2 \\
Tellurium & 2.0 & 2.0 & 1.2 \\
Strontium & 2.0 & 2.0 & 1.2 \\
Ruthenium & 2.0 & 2.0 & 1.2 \\
Lanthanum & 2.0 & 2.0 & 1.2 \\
Cerium & 2.0 & 2.0 & 1.2 \\
Barium & 2.0 & 2.0 & 1.2 \\
Tritium & 1.0 & 1.0 & 1.0 \\
& & & \\
\hline
\end{tabular}

\subsubsection{Decontamination Factors of Reactor Room Sprays}

The PRAST input parameter which gives the DFs of confinement sprays for fission products is espdf. The DFs for iodine removal by sprays were calculated, based on CONTAIN calculations [13], to range from 1.2 to 10 , with most values in the range from 1.2 to 2.0. For aerosol particles in the relevant size range (less than $1 \mu \mathrm{m}$ ), spray removal is essentially negligible. The confinement states for ecdf and ecdfmn (described in section 4.2.2.2) were also used for espdf. Table 4-14 summarizes the values calculated for espdf. 
Table 4-14. Decontamination Factors of Process Room Sprays

\begin{tabular}{lllllll}
$\begin{array}{l}\text { Group } \\
\text { Name }\end{array}$ & $\begin{array}{l}\text { Building } \\
\text { Failure }\end{array}$ & $\begin{array}{c}\text { Building } \\
\text { Breach } \\
\text { with } \\
\text { Dampers } \\
\text { Closed }\end{array}$ & $\begin{array}{c}\text { Building } \\
\text { Breach } \\
\text { with } \\
\text { Dampers } \\
\text { Open }\end{array}$ & $\begin{array}{c}\text { AACS } \\
\text { Operating }\end{array}$ & Fan Failure & $\begin{array}{c}\text { Damper } \\
\text { Closure }\end{array}$ \\
\hline Noble Gas & 1.0 & 1.0 & 1.0 & 1.0 & 1.0 & 1.0 \\
Iodine & 1.0 & 2.0 & 1.4 & 1.3 & 2.5 & 100.0 \\
Cesium & 1.0 & 1.0 & 1.0 & 1.0 & 2.0 & 10.0 \\
Tellurium & 1.0 & 1.0 & 1.0 & 1.0 & 2.0 & 10.0 \\
Strontium & 1.0 & 1.0 & 1.0 & 1.0 & 2.0 & 10.0 \\
Ruthenium & 1.0 & 1.0 & 1.0 & 1.0 & 2.0 & 10.0 \\
Lanthanum & 1.0 & 1.0 & 1.0 & 1.0 & 2.0 & 10.0 \\
Cerium & 1.0 & 1.0 & 1.0 & 1.0 & 2.0 & 10.0 \\
Barium & 1.0 & 1.0 & 1.0 & 1.0 & 2.0 & 10.0 \\
Tritium & 1.0 & 1.0 & 1.0 & 1.0 & 1.0 & 1.0 \\
& & & & & & \\
\hline
\end{tabular}




\subsubsection{Decontamination Factors of AACS Filters}

The PRAST input parameter which gives the DFs of the confinement filters for fission products is fltdf. The AACS filters are assumed to be 99.7 percent $(D F=333)$ efficient in trapping iodine and aerosols. Table 4-15 summarizes the values calculated for fltdf.

The $\mathrm{K}$ reactor filter compartments are to be upgraded during the cooling tower tie-in outage ( $\sim$ December 1992). The decontamination factors of the filter compartments will have to be evaluated after installation is complete.

Table 4-15. Decontamination Factors of AACS Filters

Group Name Decontamination Factors

Noble Gas 1.0

Iodine 333.0

Cesium 333.0

Tellurium

333.0

Strontium 333.0

Ruthenium 333.0

Lanthanum 333.0

Cerium 333.0

Barium 333.0

Tritium

1.0 


\subsection{Transfer Fractions}

There are four transfer fraction parameters which are input to PRAST: 1) fracfl - the fraction of early release that exits the above grade confinement in the first and second periods, 2) ebyp - the fraction of fission products that bypasses the filters in first and second periods, 3) mbyp - the fraction of the above grade release that bypasses the filters during the third period, and 4) lbyp - the fraction of fission products released below grade which bypass the filters.

\subsubsection{Early Phase Transfer Fractions}

The PRAST input parameter fracfl describes the transfer fraction of fission products to exit (transfer to either the environment or the filters) the above grade confinement by the start of the late phase (Periods 1 and 2). The fracfl input parameter has one value for all of the ten element groups in six possible confinement states. All ten element groups are assumed to be purged from the above grade confinement at the same rate. The six confinement states examined for the above grade confinement DFs were 1) total confinement building failure (due to a seismic event or a catastrophic vessel failure), 2) confinement building breach with closure of the main exhaust dampers, 3) confinement building breach with the main exhaust dampers open, 4) airborne activity confinement system (AACS) operating normally, 5) AACS fan failure, and 6) closure of the main exhaust dampers with no building breach. These confinement states are the same as the ones used to define ecdf and ecdfmn, the DFs for above grade and below grade confinement.

The PRAST values for fracfl depend on the failure mode of confinement structures and on the nature of the flow through the confinement system. The assigned values are taken from a series of MELCOR calculations performed to evaluate confinement system performance under severe accident conditions. These calculations are described in [12]. Table 4-16 summarizes the values calculated for fracfl.

Table 4-16. Fraction of Fission Products Purged from the Confinement by the Start of the Late Phase

\begin{tabular}{|c|c|c|c|c|c|}
\hline $\begin{array}{l}\text { Building } \\
\text { Failure }\end{array}$ & $\begin{array}{l}\text { Building } \\
\text { Breach } \\
\text { with } \\
\text { Dampers } \\
\text { Closed }\end{array}$ & $\begin{array}{c}\text { Building } \\
\text { Breach } \\
\text { with } \\
\text { Dampers } \\
\text { Open }\end{array}$ & $\underset{\text { Operating }}{\text { AACS }}$ & Fan Failure & $\begin{array}{l}\text { Da mper } \\
\text { Closure }\end{array}$ \\
\hline
\end{tabular}

All Element Groups

$0.5 \quad 0.05$

0.02

0.25

0.04

0.01 
The PRAST input parameter ebyp describes the transfer fraction of fission products to bypass the filters by the start of the late phase (Periods 1 and 2). The ebyp input parameter has one value for all of the ten element groups for each of three filter bypass levels (complete $=1.0$, partial $=0.5$, and no bypass $=0.0$ ). All ten element groups are assumed to bypass the filters at the same rate.

\subsubsection{Intermediate Phase Transfer Fractions}

The PRAST input parameter mbyp describes the transfer fraction of fission products purged from the above grade confinement due to an energetic event (during Period 3). This parameter is only used if the energetic event does not cause building failure. PRAST has been coded to set the transfer fraction to 1.0 if the energetic event causes building failure. The mbyp input parameter has one value for all of the ten element groups. All ten element groups are assumed to be purged from the above grade confinement at the same rate. This value, which is set equal to 0.5 , is based on MELCOR calculations of confinement performance. These calculations are documented in [12].

\subsubsection{Late Phase Transfer Fractions}

The PRAST input parameter lbyp describes the transfer fraction of fission products purged from the above and below grade confinement during the late phase of the accident (Period 4). The lbyp input parameter has one value for all of the ten element groups for five levels of bypass. All ten element groups are assumed to be purged from the confinement at the same rate. The values are based on the levels of late filter bypass specified by the PRAST Dimension 13 as given in [2]. Table 4-17 summarizes the values used for lbyp.

Table 4-17. Fraction of Fission Products that Bypass the Confinement Filters in the Late Phase

Complete High Moderate Low Very No
Bypass Bypass Bypass Bypass Low Bypass

\begin{tabular}{lllllll}
\hline & & & \multicolumn{5}{c}{ Bypass } \\
\hline $\begin{array}{l}\text { All } \\
\text { Element }\end{array}$ & 1.0 & 0.9 & 0.6 & 0.2 & 0.1 & 0.0 \\
Groups & & & & & & \\
\hline
\end{tabular}




\subsection{Source Term Characteristics}

The characteristics of a source term which are not related to the magnitude of the release but are required for the calculation of the consequences of a fission product release are as follows: release timings, release durations, elevation of release, and thermal energy associated with the release.

\subsubsection{Release Timings}

The release timing that has a PRAST input parameter directly associated with it is the initial release timing (Period 1). The release timings for the remaining periods are calculated by PRAST based on the initial release timing and the durations of the previous periods. For example, if the release in Period 1 began at $300 \mathrm{~s}$, and the durations of Periods 1 and 2 were $90 \mathrm{~s}$ and $30 \mathrm{~s}$, respectively, the release timing of Period 3 would be $420 \mathrm{~s}$ $(300+90+30)$.

The PRAST input parameter trelse describes the time after scram (in seconds) in which the Period 1 release begins. It has three possible values which are immediate, delayed and long delay.

An immediate release ( 5 minutes) can result from a loss of pumping accident (LOPA), a loss of coolant accident (LOCA), an anticipated transient without scram (ATWS), or a loss of primary circulation (LOPC). This value is based on the TRAC calculations [14] for a LOCA and a LOPA.

A delayed release (45 minutes) can result from a LOPA due to small secondary cooling water leak, a LOCA with the emergency core cooling system (ECCS) functioning, or a LOCA with internal flooding. This value is based on the TRAC calculations [14] for a LOCA and a LOPA and engineering judgement as described in [3].

A long delayed release (2 hours) can result from a Loss of Heat Sink Accident (LOHSA), a loss of river water accident or a vented loss of primary circulation. This value is based on the TRAC calculations [14] for a LOHSA.

\subsubsection{Release Durations}

The PRAST input parameters describing the durations of the five time periods are tperd1, tperd2, tperd3, tperd4, and tperd5.

\subsubsection{Duration of Time Period 1 (Fuel Melt)}

Period 1 has three possible durations depending on how fuel melts. As described in Section 4.1.1.1, PRAST considers three scenarios for fuel melt: 1) non-energetic melt, 2) recriticality involving 25 percent of the core or 3) power excursion involving 10 percent of the core. Each of these scenarios has a different duration assigned to it as discussed below. 
The duration of Period 1 for a non-energetic melt, based on fuel melting calculations performed using MELCOR/SR and MELSRP as discussed in section 4.3 of [17], is 300 seconds. The duration of Period 1 for a recriticality event, based on analysis of recriticality in SRS reactors as documented in [22], is 90 seconds. The duration of Period 1 for a power excursion is 30 seconds. There has been no detailed anaysis of the melting of fuel due to a power excursion since it has been deemed very unlikely. Preliminary investigation of this scenario indicates that fuel melt will occur very rapidly, therefore, a value of 30 seconds was assigned.

\subsubsection{Duration of Time Period 2 (Fuel Debris Heat Up)}

Period 2 has three possible durations depending on how the fuel debris heats up. PRAST considers three scenarios for duration of debris heat up: 1) the heat up does not occur due to an energetic event at the bottom of the vessel, 2) the heat up is stopped when an energetic event occurs in the outlet piping or 3) the heat up is stopped when the vessel fails thermally. Each of these scenarios has a different duration assigned to it as discussed below.

The duration of Period 2 if no heat up occurs is 30 seconds. This value was estimated allowing for relocation of the fuel prior the energetic event which precludes the heat up. The duration of Period 2 assuming the fuel relocates to the outlet piping before a steam explosion fails the pipe is 120 seconds [7]. The duration of Period 2 assuming that the debris heats up to at least $1400 \mathrm{~K}$ before the primary system fails is 600 seconds [7].

\subsubsection{Duration of Time Period 3 (Vessel Failure)}

Period 3 has two possible durations depending on how the vessel failure occurs. PRAST considers two scenarios: 1) an energetic event occurs in the pump room 2) no energetic event occurs. Each of these scenarios has a different duration assigned to it as discussed below.

The duration of Period 3 if there is an energetic event in the primary system or in the pump room is 30 seconds. The duration of Period 3 for assuming no energetic event occurs is 0 seconds. These values have been assigned using engineering judgement.

\subsubsection{Duration of Time Period 4 (Core Concrete Interaction)}

Period 4 has two possible durations depending on the interactions that occur between the molten core debris and the concrete pump room floor. PPAST considers two scenarios: 1) MCCI occurs, and 2) MCCI does not occur. Each of these scenarios has a different duration assigned to it as discussed below.

The duration of Period 4 if MCCI occurs is 36000 seconds. The duration of Period 4 if MCCI does not occur is 0 seconds. As documented in Section 4.9 of [17] it would take approximately 10 hours to oxidize the entire core. Once the core is completely oxidized the core concrete interactions would cease. 


\subsubsection{Duration of Time Period 5 (Delayed Releases)}

Period 5 has three possible durations depending on the status of the filters. The duration of Period 5 if filter burn occurs is 21000 seconds. The duration of Period 5 if filter desorption occurs is 7200 seconds. The duration of Period 5 if neither filter burn nor desorption occur is 0 seconds.

\subsubsection{Elevation of Release}

The PRAST input parameter elev is used to describe the elevation of the fission product release. It takes on three values which correspond to the possible the transfer paths for radionuclide release. If the release is from the below grade atmosphere directly to the environment, the release elevation is assumed to be 0.0 (ground level). If the release is from the above grade atmosphere directly to the environment, the release elevation is assumed to be 20 meters above ground level (i.e., at the top of the reactor room). Finally, if release is through the filters and the stack, the release location is assumed to be 60 meters above ground level (i.e., at the exit of the stack). The transfer path depends, of course, on any structural failures above and below grade, and on whether radionuclides bypass the filters.

\subsubsection{Thermal Energy of Release}

The PRAST input parameter heatr is used to describe the thermal energy of the fission product release. It takes on one of ten possible values depending on the accident scenario. The CONTAIN calculations documented in [13] were used to estimate the values for the ten scenarios. Table 4-18 summarizes the values used for heatr. 
WSRC-RP-92-973

Table 4-18. Thermal Energy Associated with Fission Product Release Scenario

Energy (J)

Normal Filtration

Steam Explosion

$2.00 \mathrm{E}+06$

Power Excursion

$7.00 \mathrm{E}+06$

Natural Circulation through the Above Grade

$3.00 \mathrm{E}+07$

Desorption Filtration

Filter Burn

Energetic Hydrogen Burn

Continuous Hydrogen Burn

$1.00 \mathrm{E}+06$

$3.00 \mathrm{E}+06$

$6.00 \mathrm{E}+06$

$1.00 \mathrm{E}+08$

Uncovered MCCI

$5.00 \mathrm{E}+07$

Unused

$1.00 \mathrm{E}+07$

N/A 


\subsection{Chemical Characteristics of the Release}

The radionuclides in the second fission product group, iodine, are released as elemental iodine and cesium iodide. Since the transport characteristics of elemental iodine and cesium iodide differ greatly, an eleventh fission product group which represents cesium iodide is created within PRAST. The PRAST input parameter, fi2, describes the fraction of iodine which is released in the elemental form. The value of $f i 2$ is 0.05 , thus, the iodine released in severe accidents is 5 percent elemental iodine and 95 percent cesium iodide. This value is based on the analysis described in [15]. 


\subsection{DHSTRIBUTIONS OF SAMPLED INPUT PARAMETERS}

The PRAST computer code has the ability to use a sample of the distributions of the input parameter values which are treated as uncertain. Appendix B gives the distribution definitions of these sampled parameter values as used in the K Reactor PRA. Some of the input parameters have a total of five points specified for each value (lower bound, lower percentile, median, upper percentile, and upper bound), however, only three are required to define a distribution (lower bound, median, and upper bound). The distributions are based on uncertainties in the analyses which were performed to evaluate the parameter and on engineering judgement. 
WSRC-RP-92-973

This Page Intentionally Left Blank 
WSRC-RP-92-973

\subsection{CONCLUSIONS}

This report documents the basis for the PRAST input parameters as used in the SRS Reactor PRA (Revision 0). Appendix A gives a listing of the input file that contains the median values of the input parameters. Appendix B gives the distributions assumed for the uncertain parameters. 
WSRC-RP-92-973

This Page Intentionally Left Blank 


\subsection{REFERENCES}

1 Severe Accident Risks: An Assessment for Five U. S. Nuclear Power Plants, NUREG-1150, Vol. 1 Sandia National Laboratories, Albuquerque, NM, (1990).

2 D. P. Kearnaghan, The Froduction Reactor Algorithm for Source Terms (PRAST), A Cumputer code Used in Estimating Source Terms for SRS Reactors (U). WSRC-RP-92-700, Westinghouse Savannah River Company, Aiken, SC (1992).

3 N. D. Woody and M. D. Brandyberry, Savannah River Site Safety Assessment (U), WSRC-RP-91-041-DRAFT, Westinghouse Savannah River Company, Aiken, SC (1991).

4 Severe Accident Assessment Program, Code Requirements Document: MELCOR/SR, A Computer Code for Evaluating Severe Accident Progression in Heavy Water Reactors; Reference Manuals and Users Guide, WSRC-RP-89-1030, Westinghouse Savannah River Company, Aiken, SC (1989).

5 E. R. Copus, et al., Core-Concrete Interactions Using Molten Aluminum on a Siliceous Basemat: The SRL-1 Experiment, SAND89-2166, Sandia National Laboratories, Albuquerque, NM (1991).

6 F. T. Harper, et al., Evaluation of Severe Accident Risks: Quantification of Major Input Parameters, NUREG/CR-4551, SAND86-1309, Vol. 2, Rev. 1, Part 4, Sandia National Laboratories, Albuquerque, NM (1992).

$7 \quad$ S. D. Clement, et al., Analysis of Debris Behavior at Savannah River Site Reactors for the PRA (U). WSRC-RP-92-836, Westinghouse Savannah River Company, Aiken, SC (1992).

8 E. C. Beahm, et al., "Iodine Volatility", Proceedings of the ANS Topical Meeting on Fission Product Behavior and Source Term Research, July 15-19, 1984, Snowbird, UT (1984).

$9 \quad$ S. Wisbey, et al., 1986, Iodine Behavior in Containment Under LWR Accident Conditions, NUREG/CP-0078, p. 6-29, Oak Ridge National Laboratory (September 1986).

10 D. A. Powers, et al., VANESA: A Mechanistic Model of Radionuclide Release and Aerosol Generation During Core Debris Interactions with Concrete, NUREG/CR-4308 (September, 1985). 
11 R. E. Blose, et al., SWISS: Sustained Heated Metallic Melt/Concrete Interactions with Overlying Water Pools, NUREG/CR-4727, SAND851546, Sandia National Laboratories, Albuquerque, NM (1987).

K. C. Wagner, et al., Analysis of Confinement Response at Savannah River Site Reactors for the PRA (U). WSRC-RP-92-977, Westinghouse Savannah River Company, Aiken, SC (1992).

13 K. R. O'Kula, The CONTAIN Code for Analysis of SRS Reactor Confinement System Response During Severe Accidents (U), WSRCTR-90-326, Westinghouse Savannah River Company, Aiken, SC (Draft).

14 Sartor, et al., Analysis of Thermal Hydraulic Transients (LOPA, LOCA, and LOHSA) at the Savannah River Site Reactors for the PRA (U), WSRC-RP-92-920, Westinghouse Savannah River Company, Aiken, SC (1992).

15 J. P. Adams \& D. L. Hagrman, An Analytical Assessment of the Chemical Form of Fission Products During Postulated Severe Accidents in the SRS Production Reactors (U), WSRC-RP-90-1365, Westinghouse Savannah River Company, Aiken, SC (1990).

16 W. H. Baker \& W. L. Ferrell, The Accident Progression Event Tree: A Logic Model for the Progression of Postulated Severe Accidents in SRS Reactors, WSRC-RP-91-965, Westinghouse Savannah River Company, Aiken, SC (1992).

17 R. T. Bailey et. al, Quantification of Input for the Accident Progression Event Tree (U), WSRC-RP-92-977, Westinghouse Savannah River Company, Aiken, SC (1992).

18 M.R. Kuhlman, et al., CORSOR User's Manual, NUREG/CR-4173, BMI-2122, Battelle Memorial Institute, 1985.

19 F.R. Bruce, et al., Nuclear Safety Program Semiannual Progress Report for Period Ending June 30, 1963, ORNL-3483, Oak Ridge National Laboratory, 1963.

20 P. G. Whitkop, Summary of the Second Series of SRL Fuel Melt Experiments, DPST-87-412, E.I. du Pont de Nemours and Company, Savannah River Laboratory, July 1987.

21 R. N. Oehlberg, et al., "Scrubbing of Radionuclide Aerosols in Water Pools", Proceedings of the ANS Topical Meeting on Fission Product Behavior and Source Term Research, July 15-19, 1984, Snowbird, UT (1984). 
22 S. D. Clement, et al., Analysis of Recriticality at Savannah River Site Reactors for the PRA (U). WSRC-RP-92-443, Westinghouse Savannah River Company, Aiken, SC (1992).

23 D. R. Bradley, et al., Analysis of Molten Core Concrete Interactions at Savannah River Site Reactors for the PRA (U). WSRC-RP-92-1010, Westinghouse Savannah River Company, Aiken, SC (1992). 
WSRC-RP-92-973

This Page Intentionally Left Blank 
Appendix A

PRAST Parameter Input Listing

A-1 


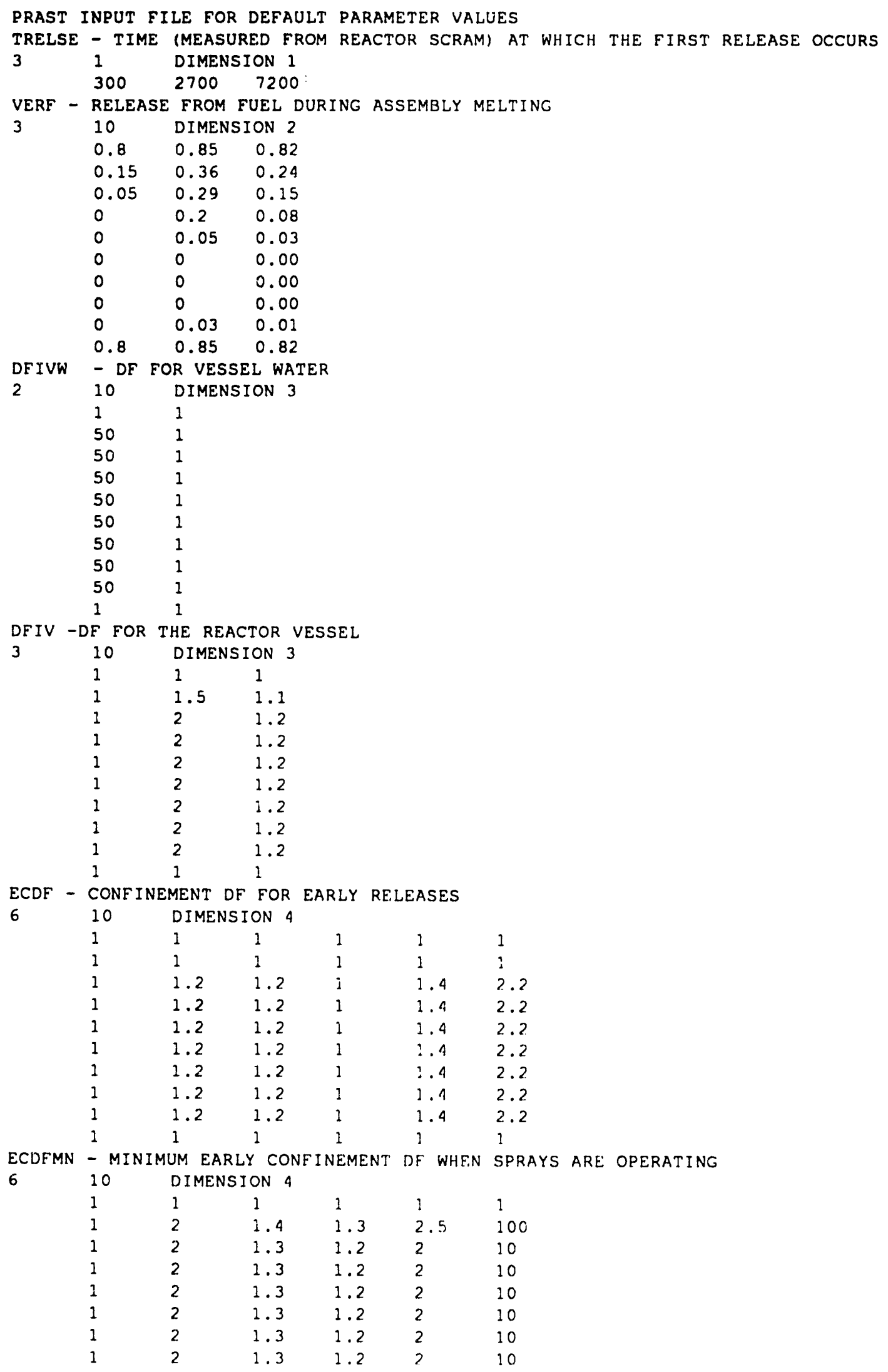

$\begin{array}{llllll}1 & 1 & 1 & 1 & 1 & 1 \\ 1 & 2 & 1.4 & 1.3 & 2.5 & 100 \\ 1 & 2 & 1.3 & 1.2 & 2 & 10 \\ 1 & 2 & 1.3 & 1.2 & 2 & 10 \\ 1 & 2 & 1.3 & 1.2 & 2 & 10 \\ 1 & 2 & 1.3 & 1.2 & 2 & 10 \\ 1 & 2 & 1.3 & 1.2 & 2 & 10 \\ 1 & 2 & 1.3 & 1.2 & 2 & 10\end{array}$




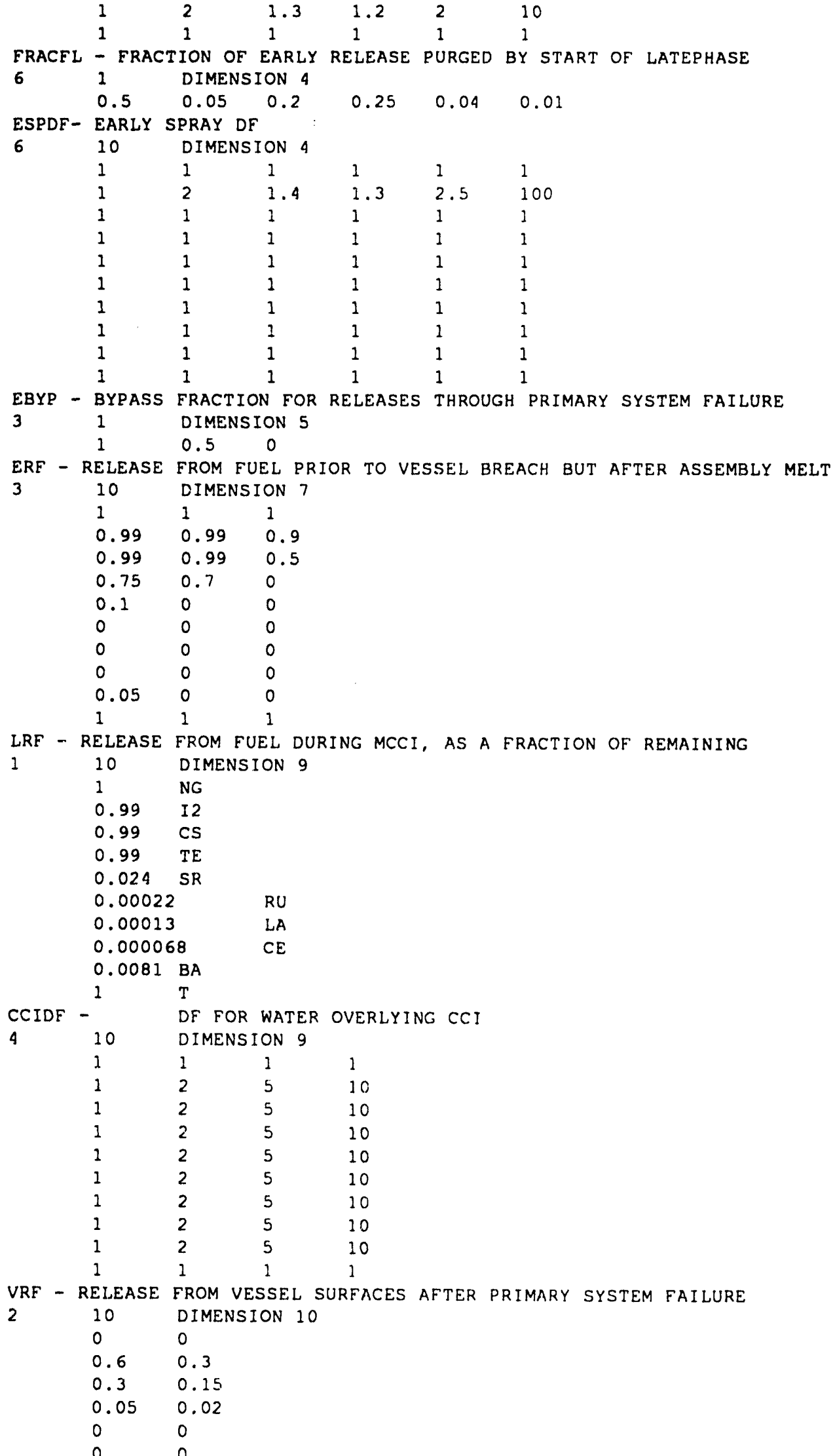




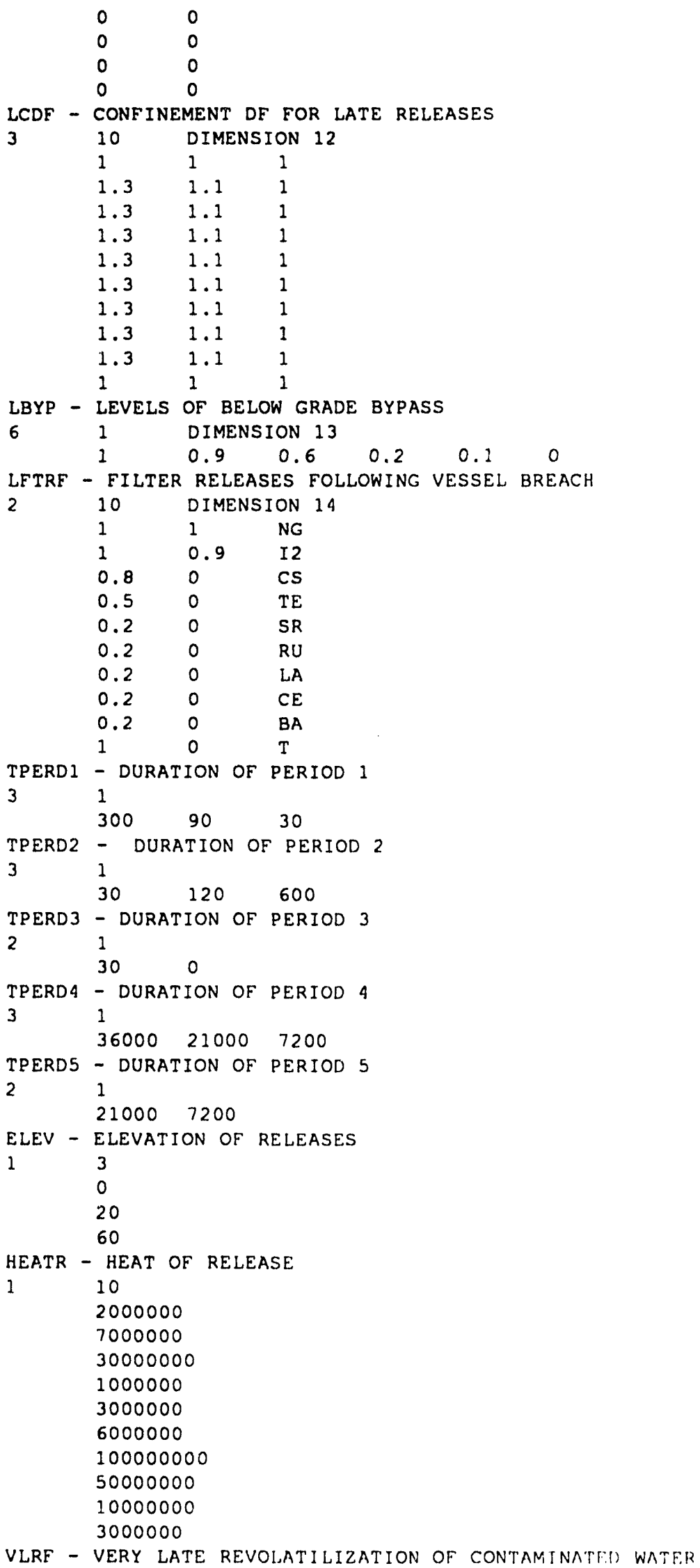




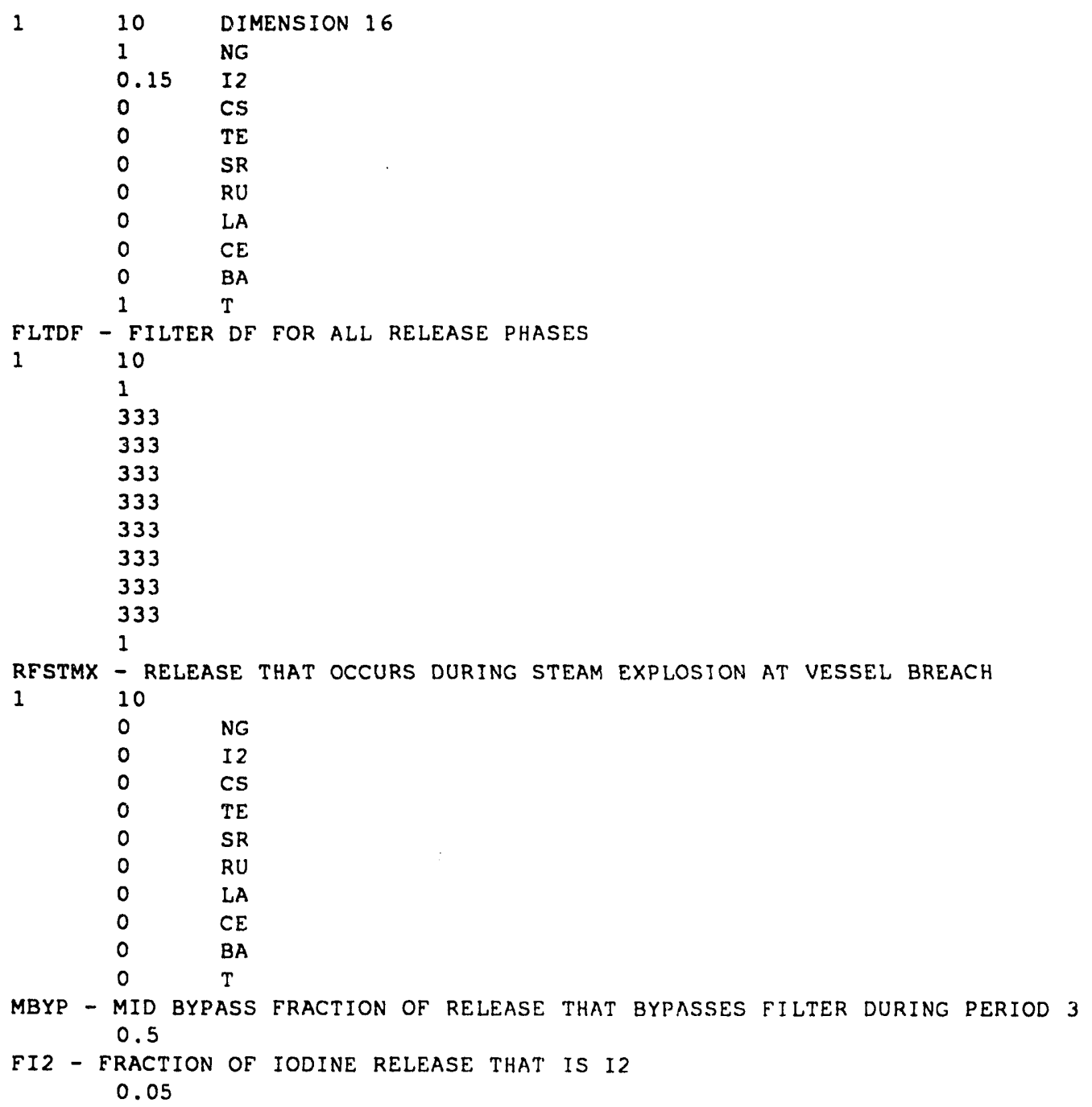


WSRC-RP.92-973

This Page Intentionally Left Blank

A.6 
Appendix B

Distributions of the Sampled PRAST Input Parameter Values 
This Page Intentionally Left Blank 
WSRC-RP-92-873

B.1 Release Fractions During Fuel Melt (verf)

Table B.1-1 Distribution of Release Fractions During a Non-Energetic Melt

\begin{tabular}{|c|c|c|c|c|c|}
\hline Group & & 5 th & & 95th & \\
\hline Name & Lower Bound & Percentile & Median & Percentile & Upper Boumd \\
\hline Noble Gas & 0.0 & 0.70 & 0.80 & 0.99 & 1.00 \\
\hline Iodine & 0.0 & 0.10 & 0.15 & 0.50 & 1.00 \\
\hline Cesium & 0.0 & 0.01 & 0.05 & 0.25 & 1.00 \\
\hline Tellurium & 0.0 & 0.0 & 0.0 & 0.01 & 1.00 \\
\hline Tritium & 0.0 & 0.70 & 0.80 & 0.99 & 1.00 \\
\hline
\end{tabular}

Table B.1-2 Distribution of Release Fractions During Melt for a Recriticality Event

\begin{tabular}{llcccc}
$\begin{array}{l}\text { Groum } \\
\text { Name }\end{array}$ & Lower Bound & $\begin{array}{c}\text { 5th } \\
\text { Percentile }\end{array}$ & Median & $\begin{array}{c}\text { 95th } \\
\text { Percentile }\end{array}$ & Upper Bound \\
\hline \hline & & & & & \\
Noble Gas & 0.0 & 0.75 & 0.85 & 0.99 & 1.00 \\
Iodine & 0.0 & 0.30 & 0.36 & 0.60 & 1.00 \\
Cesium & 0.0 & 0.10 & 0.29 & 0.50 & 1.00 \\
Tellurium & 0.0 & 0.05 & 0.20 & 0.25 & 1.00 \\
Strontium & 0.0 & 0.01 & 0.05 & 0.25 & 1.00 \\
Barium & 0.0 & 0.01 & 0.03 & 0.25 & 1.00 \\
Tritium & 0.0 & 0.75 & 0.85 & 0.99 & 1.00 \\
& & & & & \\
\hline
\end{tabular}


Table B.1-3 Distribution of Release Fractions During Melt for a Power Excursion

\begin{tabular}{|c|c|c|c|c|c|}
\hline Group & & 5 th & & 95th & \\
\hline Name & Lower Bound & Percentile & Median & Percentile & Upper-Boumd \\
\hline Noble Gas & 0.0 & 0.75 & 0.82 & 0.99 & 1.00 \\
\hline Iodine & 0.0 & 0.20 & 0.24 & 0.80 & 1.00 \\
\hline Cesium & 0.0 & 0.10 & 0.15 & 0.80 & 1.00 \\
\hline Tellurium & 0.0 & 0.02 & 0.08 & 0.10 & 1.00 \\
\hline Strontium & 0.0 & 0.01 & 0.02 & 0.10 & 1.00 \\
\hline Ruthenium & 0.0 & 0.0 & 0.0 & 0.05 & 1.00 \\
\hline Lanthanum & 0.0 & 0.0 & 0.0 & 0.05 & 1.00 \\
\hline Cerium & 0.0 & 0.0 & 0.0 & 0.05 & 1.00 \\
\hline Barium & 0.0 & 0.00 & 0.01 & 0.10 & 1.00 \\
\hline Tritium & 0.0 & 0.75 & 0.82 & 0.99 & 1.00 \\
\hline
\end{tabular}


WSRC-RP-92-973

B2 Release Fractions During Heat Up of Core (erf)

Table B.2-1 Distribution of Release Fractions During Core Debris Heatup $(1700 \mathrm{~K})$

\begin{tabular}{lccccc}
$\begin{array}{l}\text { Group } \\
\text { Name }\end{array}$ & Lower Bound & $\begin{array}{c}\text { 5th } \\
\text { Fercentile }\end{array}$ & Median & $\begin{array}{c}\text { 95th } \\
\text { Percentile }\end{array}$ & $\begin{array}{l}\text { Upper Bound } \\
\text { Iodine }\end{array}$ \\
\hline & 0.0 & 0.90 & 0.99 & N/A & 1.00 \\
Cesium & 0.0 & 0.90 & 0.99 & N/A & 1.00 \\
Tellurium & 0.0 & 0.25 & 0.75 & 0.95 & 1.00 \\
Stontium & 0.0 & 0.05 & 0.10 & 0.40 & 1.00 \\
Barium & 0.0 & 0.01 & 0.05 & 0.20 & 1.00 \\
& & & & & \\
\hline
\end{tabular}

Tuble B.2-2 Distribution of Release Fractions During Core Debris Heatup (1400 K)

\begin{tabular}{lccccc}
$\begin{array}{l}\text { Group } \\
\text { Name }\end{array}$ & Lower Bound & $\begin{array}{c}\text { 5th } \\
\text { Percentile }\end{array}$ & Median & $\begin{array}{c}\text { 95th } \\
\text { Percentile }\end{array}$ & Upper Bound \\
\hline Iodine & 0.0 & 0.90 & 0.99 & N/A & 1.00 \\
Cesium & 0.0 & 0.90 & 0.99 & N/A & 1.00 \\
Tellurium & 0.0 & 0.20 & 0.70 & 0.90 & 1.00 \\
\hline
\end{tabular}


WSRC-RP-92-973

Table B.2-3 Distribution of Release Fractions During Core Debris Heatup $(1000 \mathrm{~K})$

\begin{tabular}{lccccc}
$\begin{array}{c}\text { Group } \\
\text { Name }\end{array}$ & Lower Bound & $\begin{array}{c}\text { 5th } \\
\text { Percentile }\end{array}$ & Median & $\begin{array}{c}\text { 95th } \\
\text { Percentile }\end{array}$ & Upper Bound \\
\hline \hline & & & & & \\
Iodine & 0.0 & 0.25 & 0.90 & 0.99 & 1.00 \\
Cesium & 0.0 & 0.10 & 0.50 & 0.80 & 1.00 \\
\hline
\end{tabular}


WSRC-RP-92-973

B.3 Release Fractions During Molten Core-Concrete Interactions (lrf)

Table B.3-1 Distribution of Release Fractions During MCCI

\begin{tabular}{|c|c|c|c|c|c|}
\hline $\begin{array}{l}\text { Group } \\
\text { Name }\end{array}$ & Lower Bound & $\begin{array}{c}\text { 10th } \\
\text { Percentile } \\
\end{array}$ & Median & $\begin{array}{c}\text { Soth } \\
\text { Percentile } \\
\end{array}$ & Upper Bound \\
\hline Tellurium & 0.50 & 0.70 & 0.90 & 0.999 & 1.00 \\
\hline Strontium & 2.0E-04 & $6.9 \mathrm{E}-03$ & $2.4 \mathrm{E}-02$ & $5.5 \mathrm{E}-02$ & 3.2E-01 \\
\hline Ruthenium & 0.0 & $6.4 \mathrm{E}-05$ & 2.2E-04 & 9.7E-04 & 5.6E-03 \\
\hline Lanthanum & 0.0 & $3.8 \mathrm{E}-05$ & 1.3E-04 & 8.7E-04 & 5.0E-03 \\
\hline Cerium & 0.0 & 2.0E-05 & $6.8 \mathrm{E}-05$ & $3.2 \mathrm{E}-04$ & $1.8 \mathrm{E}-03$ \\
\hline Barium & 3.2E-04 & 2.3E-03 & 8.1E-03 & 1.9E-02 & 1.1E-01 \\
\hline
\end{tabular}




\section{B.4 Release Fractions Primary System Structures (vrf)}

Table B.4-1 Distribution of Primary System Revolatilization Release Fractions High Revolatilization

\begin{tabular}{llccc}
$\begin{array}{l}\text { Group } \\
\text { Name }\end{array}$ & Lower Bound & Median & 99th Percentile & Upper Bound \\
\hline & & & & \\
Iodine & 0.0 & 0.60 & 0.90 & 1.00 \\
Cesium & 0.0 & 0.30 & 0.75 & 1.00 \\
Tellurium & 0.0 & 0.05 & 0.50 & 1.00 \\
\hline
\end{tabular}

Table B.4-2 Distribution of Primary System Revolatilization Release Fractions Moderate Revolatilization

\begin{tabular}{lcccc}
$\begin{array}{c}\text { Group } \\
\text { Name }\end{array}$ & Lower Bound & Median & 99th Percentile & Upper Bound \\
\hline \hline & & & & \\
Iodine & 0.0 & 0.30 & 0.75 & 1.00 \\
Cesium & 0.0 & 0.15 & 0.50. & 1.00 \\
Tellurium & 0.0 & 0.02 & 0.25 & 1.00 \\
\end{tabular}


B.5 Release Fractions From Filters (lftrf)

Table B.5-1 Distribution of Release Fractions From Filters - Filter Burn

\begin{tabular}{lccc}
$\begin{array}{l}\text { Groum } \\
\text { Name }\end{array}$ & Lower Bound & Median & Upper Bound \\
\hline \hline & & & \\
Cesium & $1.0 \mathrm{E}-01$ & 0.80 & 1.00 \\
Tellurium & 0.0 & 0.50 & 1.00 \\
Strontium & 0.0 & 0.20 & 1.00 \\
Ruthenium & 0.0 & 0.20 & 1.00 \\
Lanthanum & 0.0 & 0.20 & 1.00 \\
Cerium & 0.0 & 0.20 & 1.00 \\
Barium & 0.0 & 0.20 & 1.00 \\
& & & \\
\hline
\end{tabular}

Table B.5-2 Distribution of Release Fractions From Filters - Filter Desorption

\begin{tabular}{lccc}
$\begin{array}{c}\text { Group } \\
\text { Name }\end{array}$ & Lower Bound & Median & Upper Bound \\
\hline & 0.50 & 0.90 & 1.00 \\
\hline
\end{tabular}


B.6 Release Fractions From Contaminated Water (vlrf)

Table B.6-1 Distribution of Release Fractions From Contaminated Water

\begin{tabular}{lccccc}
$\begin{array}{c}\text { Group } \\
\text { Name }\end{array}$ & Lower Bound & $\begin{array}{c}\text { 10th } \\
\text { Percentile }\end{array}$ & Median & $\begin{array}{c}\text { Soth } \\
\text { Percentile }\end{array}$ & Upper Bound \\
\hline Iodine & 0.0 & 0.05 & 0.15 & 0.50 & 1.00 \\
\hline
\end{tabular}


B.7 Decontamination Factors of Primary System Water (dfivw)

Table B.7-1 Distribution of Decontamination Factors of Primary SystemWater

\begin{tabular}{lccc}
$\begin{array}{l}\text { Group } \\
\text { Name }\end{array}$ & Lower Bound & Median & Upper Bound \\
\hline Iodine & 1 & 50 & 500 \\
Cesium & 1 & 50 & 100 \\
Tellurium & 1 & 50 & 100 \\
Strontium & 1 & 50 & 100 \\
Ruthenium & 1 & 50 & 100 \\
Lanthanum & 1 & 50 & 100 \\
Cerium & 1 & 50 & 100 \\
Barium & 1 & 50 & 100 \\
& & & \\
\hline
\end{tabular}


WSRC-RP-92-973

B.8 Decontamination Factors of Water Overlying MCCI (dfcci)

Table B.8-1 Distribution of Decontamination Factors Overlying MCCI (Dry)

\begin{tabular}{lccc}
$\begin{array}{l}\text { Group } \\
\text { Name }\end{array}$ & Lower Bound & Median & Upper Bound \\
\hline Iodine & 1 & 2 & 20 \\
Cesium & 1 & 2 & 20 \\
Tellurium & 1 & 2 & 20 \\
Strontium & 1 & 2 & 20 \\
Ruthenium & 1 & 2 & 20 \\
Lanthanum & 1 & 2 & 20 \\
Cerium & 1 & 2 & 20 \\
Barium & 1 & 2 & 20 \\
\hline
\end{tabular}


WSRC-RP-92-973

Table B.8-2 Distribution of Decontamination Factors of Water Overlying MCCI (Submerged)

\begin{tabular}{lccc}
$\begin{array}{l}\text { Group } \\
\text { Name }\end{array}$ & Lower Bound & Median & Upper Bound \\
\hline Iodine & 1 & 5 & 500 \\
Cesium & 1 & 5 & 100 \\
Tellurium & 1 & 5 & 100 \\
Strontium & 1 & 5 & 100 \\
Ruthenium & 1 & 5 & 100 \\
Lanthanum & 1 & 5 & 100 \\
Cerium & 1 & 5 & 100 \\
Barium & 1 & 5 & 100 \\
\hline
\end{tabular}


Table B.8-3 Distribution of Decontamination Factors of Water Overlying MCCI (Flooded)

\begin{tabular}{lccc}
$\begin{array}{l}\text { Group } \\
\text { Name }\end{array}$ & Lower Bound & Median & Upper Bound \\
\hline Iodine & 1 & 10 & \\
Cesium & 1 & 10 & 500 \\
Tellurium & 1 & 10 & 100 \\
Strontium & 1 & 10 & 100 \\
Ruthenium & 1 & 10 & 100 \\
Lanthanum & 1 & 10 & 100 \\
Cerium & 1 & 10 & 100 \\
Barium & 1 & 10 & 100 \\
& & & 100 \\
\hline
\end{tabular}


WSRC-RP-92-973

B.9 Decontamination Factors of Primary System Structures (dfiv)

Table B.9-1 Distribution of Decontamination Factors of Primary System Structures (Dry Vessel)

\begin{tabular}{lccc}
$\begin{array}{l}\text { Group } \\
\text { Name }\end{array}$ & Lower Bound & Median & Upper Bound \\
\hline Iodine & 1 & 1.5 & 25 \\
Cesium & 1 & 2 & 25 \\
Tellurium & 1 & 2 & 25 \\
Strontium & 1 & 2 & 25 \\
Ruthenium & 1 & 2 & 25 \\
Lanthanum & 1 & 2 & 25 \\
Cerium & 1 & 2 & 25 \\
Barium & 1 & 2 & 25 \\
\hline
\end{tabular}


Table B.9-2 Distribution Decontamination Factors of Primary System Structures (Vessel Water Energetically Expelled)

\begin{tabular}{lccc}
$\begin{array}{l}\text { Group } \\
\text { Name }\end{array}$ & Lower Bound & Median & Upper Bound \\
\hline \hline & 1 & 1.1 & 5 \\
Iodine & 1 & 1.2 & 5 \\
Cesium & 1 & 1.2 & 5 \\
Tellurium & 1 & 1.2 & 5 \\
Strontium & 1 & 1.2 & 5 \\
Ruthenium & 1 & 1.2 & 5 \\
Lanthanum & 1 & 1.2 & 5 \\
Cerium & 1 & 1.2 & 5 \\
Barium & & & 5 \\
\hline
\end{tabular}


WSRC-RP-92-973

B.10 Decontamination Factors of Process Room Sprays for Iodine (espdf)

Table B.10-1 Distribution of Decontamination Factors of Process Room Sprays for Iodine

\begin{tabular}{lccc}
\multicolumn{1}{c}{ Iodine } & Lower Bound & Median & Upper Bound \\
\hline Building Breach With Dampers Closed & 1 & 1.1 & 5 \\
Building Breach With Dampers Open & 1 & 1.2 & 5 \\
AACS Operating & 1 & 1.2 & 5 \\
Fan Failure & 1 & 1.2 & 5 \\
Damper Closure & 1 & 1.2 & 5 \\
\end{tabular}



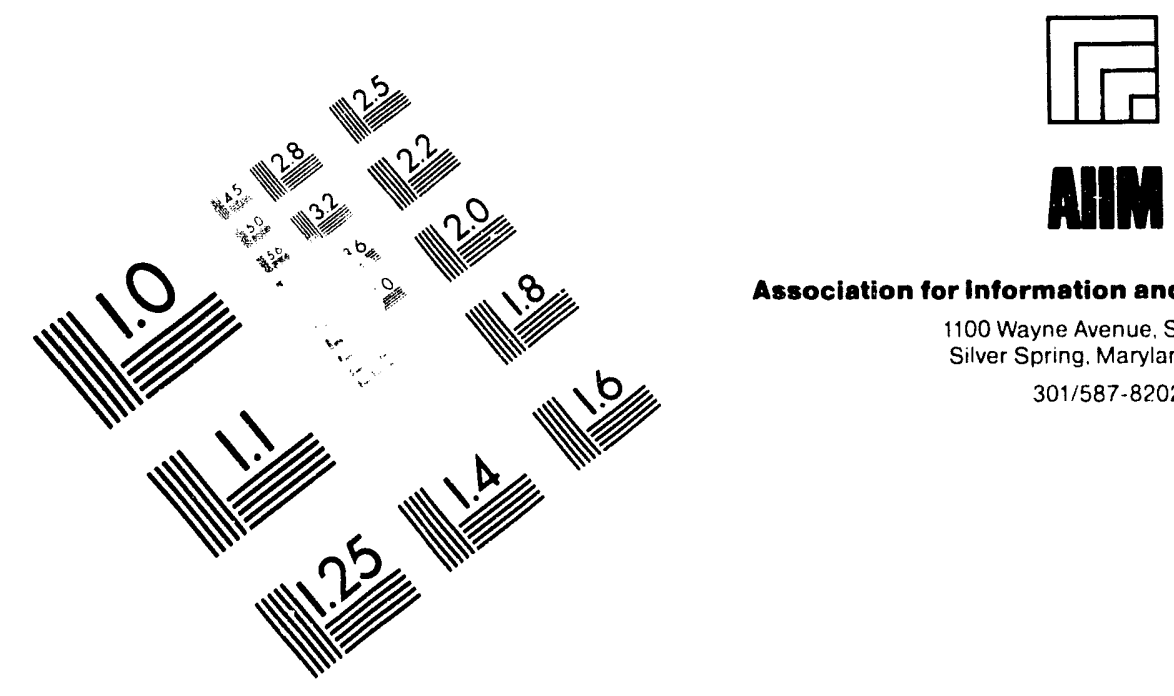

AllIM

Association for Information and Image Management

1100 Wayne Avenue. Suite 1100

Silver Spring. Maryland 20910

$301 / 587-8202$

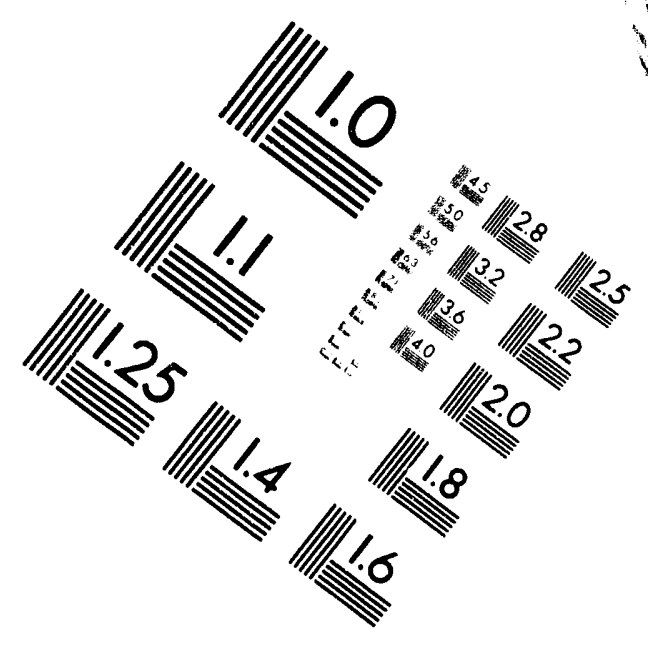

\section{Centimeter}

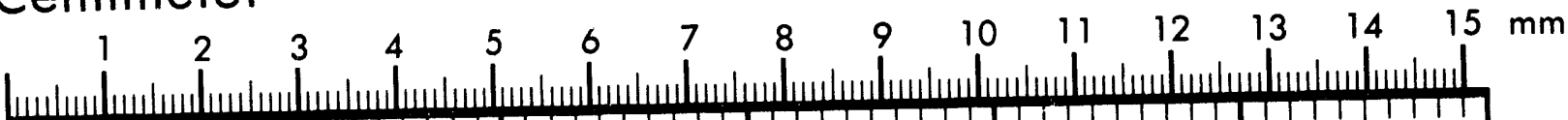

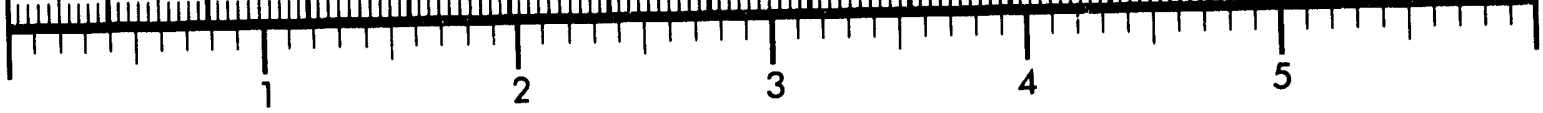
Inches
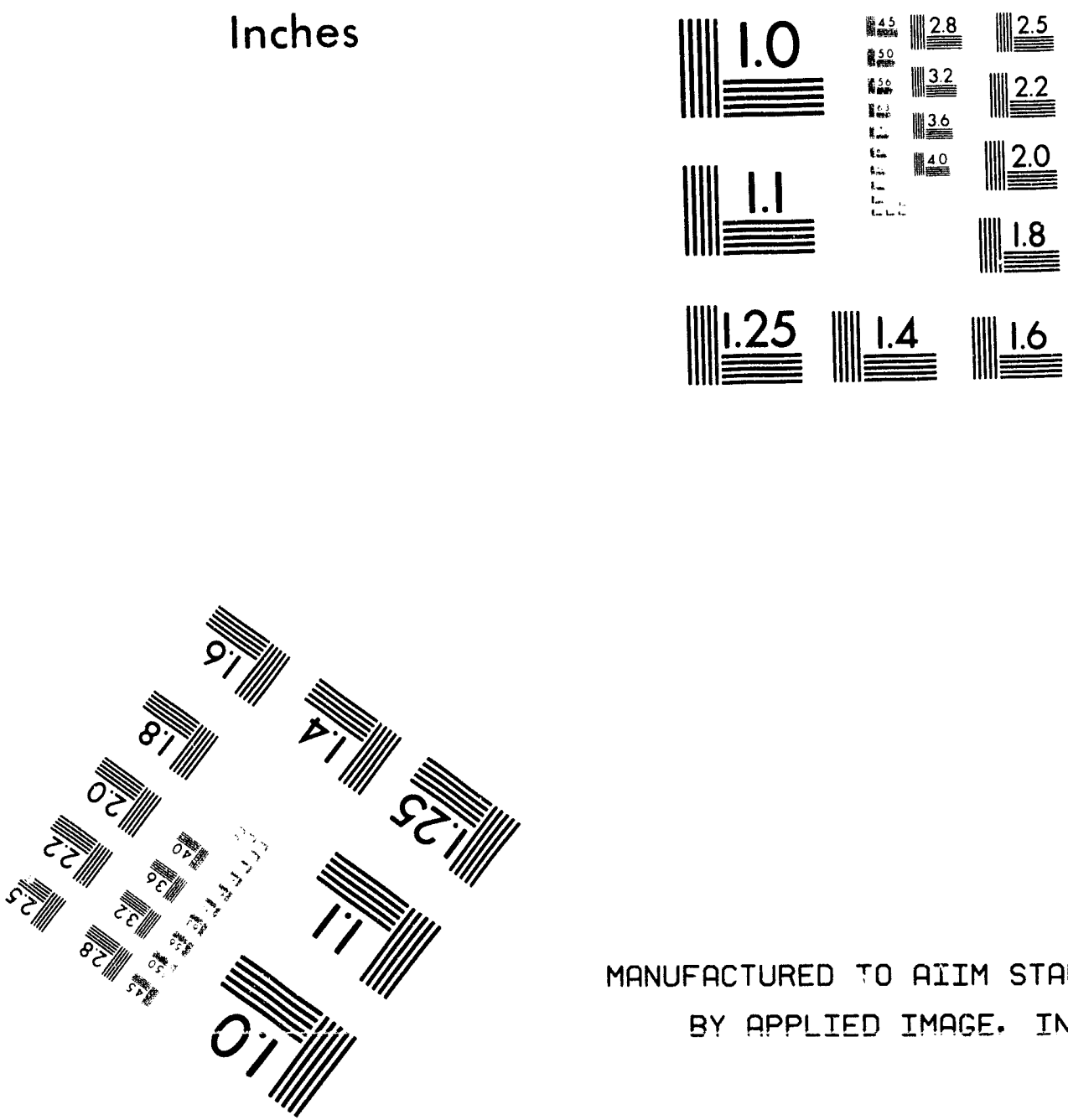

MANUFACTURED TO AIIM STANDARDS

BY PPPLIED IMAGE. INC.

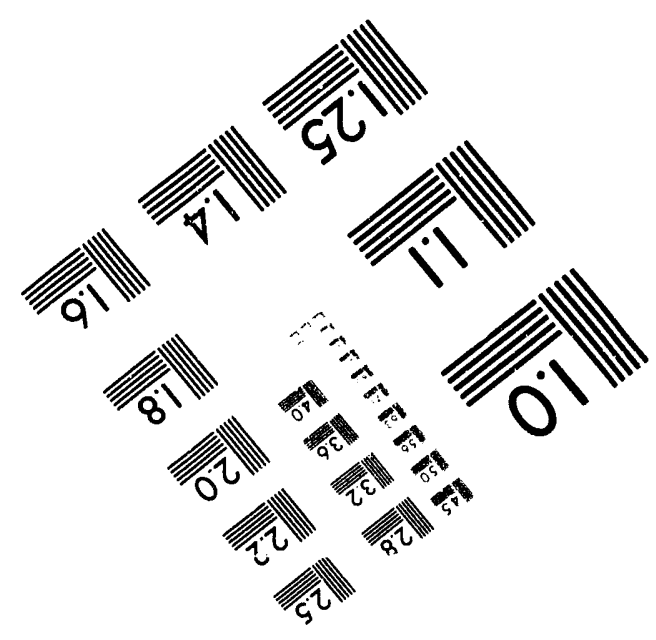



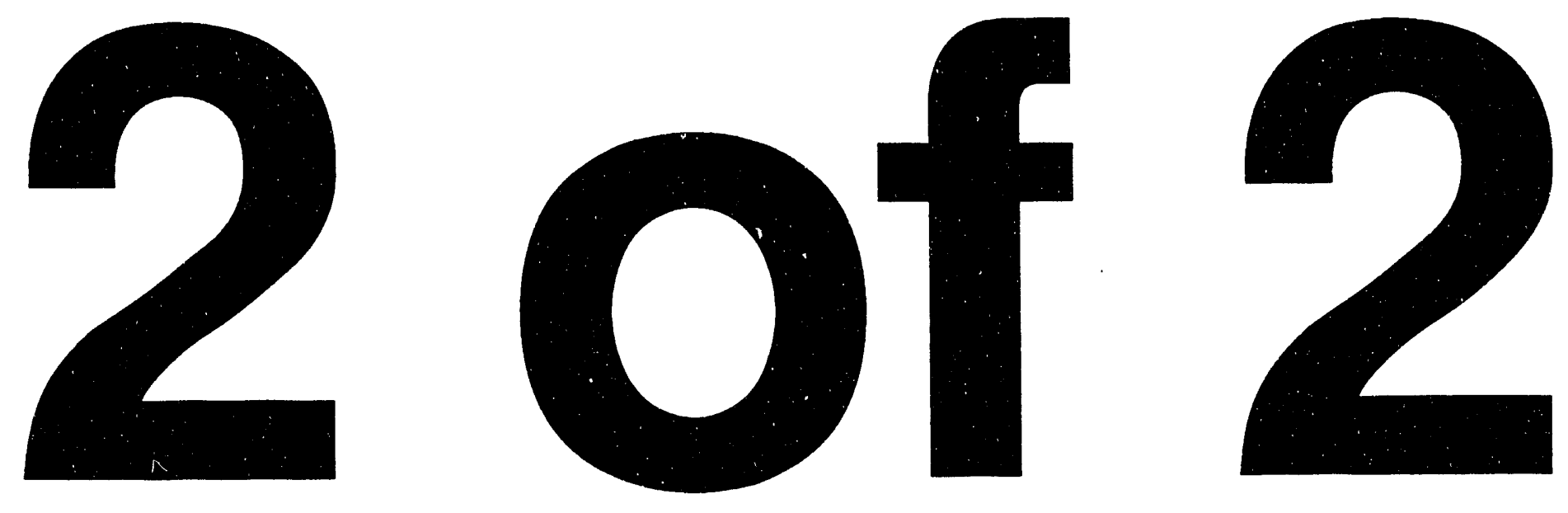
Table B.9-2 Distribution Decontamination Factors of Primary System Structures (Vessel Water Energetically Expelled)

Group

\begin{tabular}{lccc}
\multicolumn{1}{c}{ Name } & Lower Bound & Median & Upper Bound \\
\hline \hline Iodine & 1 & & 5 \\
Cesium & 1 & 1.1 & 5 \\
Tellurium & 1 & 1.2 & 5 \\
Strontium & 1 & 1.2 & 5 \\
Ruthenium & 1 & 1.2 & 5 \\
Lanthanum & 1 & 1.2 & 5 \\
Cerium & 1 & 1.2 & 5 \\
Barium & 1 & 1.2 & 5 \\
& & 1.2 & \\
\hline
\end{tabular}


WSRC-RP-92-973

B.10 Decontamination Factors of Process Room Sprays for Iodine (espdf)

Table B.10-1 Distribution of Decontamination Factors of Process Room Sprays for Iodine

Iodine

Building Breach With Dampers Closed

Building Breach With Dampers Open

AACS Operating

Fan Failure

Damper Closure
Lower Bound

Median

Upper Bound

\begin{tabular}{llll}
\hline \hline & & & \\
Building Breach With Dampers Closed & 1 & 1.1 & 5 \\
Building Breach With Dampers Open & 1 & 1.2 & 5 \\
AACS Operating & 1 & 1.2 & 5 \\
Fan Failure & 1 & 1.2 & 5 \\
Damper Closure & 1 & 1.2 & 5 \\
\hline
\end{tabular}


WSRC-RP-92-973

B.11 Early Transfer Fractions (ebyp)

Table B.11-1 Distribution of Early Filter Bypass Fraction (Partial Bypass)

Lower Bound Median

0.50

0.01

Groups

0.01

All Element Upper Bound

(1) 
WSRC-RP-92-973

B.12 Release Timing (trelse)

Table B.12-1 Initial Release Timing for Delayed Release (Seconds)

Lower Bound

Median

Upper Bound

1200

2700

3600 
WSRC-RP-92-973

B.13 Fraction of Iodine Released in the Chemical Form (fi2)

Table B.13-1 Distribution of Fraction of Iodine Released in the Flemental Form

Lower Bound

Median

95th Percentile

Upper Bound

0.0

0.05

0.10

1.0 
Distribution

Westinghouse Savannah River Company

R. T. Begley, 773-A

F. Beranek, 773-A

M. J. Hitchler, 992W-1

M. L. Cowen, 992W-1

G. H. Clare, 704-C

M. L. Hyder, 992W-1

K. R. O'Kula, 992W-1

D. B. Rankin, 704-C

D. A. Sharp, 992 W-1

D. C. Wood, 706-8C

C. E. Ahlfeld, 992W-4

R. T. Bailey, 992W-1

W. H. Baker, 992W-1

M. D. Brandyberry, 992 W-1

J. M. East, 992W-1

A. A. Simpkins, $992 \mathrm{~W}-1$

S. D. Kahook, 992W-1

D. A. Kalinich, 992W-1

D. P. Kearnaghan, 992W-1

B. J. Vonderfecht, $992 \mathrm{~W}-1$

R. W. Wittman, 992W-1

N. D. Woody, 992W-1

SRTC Records, 773-A [4]

Department of Energy, Savannah River

G. Z. Morgan, 703-41A

P. S. Shieh, 703-41A

T. M. Tran, 703-41A 


\section{External}

C.N. Amos

Science Applications International Corp.

2100 Air Park Road S.E.

Albuquerque, New Mexico 87106

P.R. Davis

PRD Consulting

1935 Sabin Drive

Idaho Falls, Idaho 83401

Kamiar M. Jamali

Dept. of Energy

OEAS-DP62/GTN

Washington, D. C. 20585

Mohsen Khatib-Rahbar

ERI

6290 Montrose Rd.

Rockville, Maryland 20852

Herbert J. C. Kouts

Defense Nuclear Facilities Safety Board 625 Indiana Avenue, N.W.

Suite 700

Washington D.C. 20004

Herbert Massey

Defense Nuclear Facilities Safety Board 625 Indiana Avenue, N.W.

Suite 700

Washington D.C. 20004

Thomas Matteson

1933 Little River Road

Flat Rock, North Carolina 27831

J. Meyer

Scientech

11821 Parklawn Dr.

Ste. 100

Rockville, Maryland 20852

David Okrent

UCLA

Boelter Hall, Room 5532

Los Angeles, CA 90024-1597 
Norman Rasmussen

M. I. T.

77 Massachusetts Ave.

Cambridge, Massachusetts 02139

Harry Reilly

EG\&G Idaho

P. O. Box 1625

Idaho Falls, ID 83415

J. D. Roarty

Defense Nuclear Facilities Safety Board

625 Indiana Avenue, N.W.

Suite 700

Washington D.C. 20004

Desmond Stack

Los Alamos National Laboratory

Group Q-6 Mail Stop K 557

Los Alamos, New Mexico 87545

D. A. Ward

2108 Pisgah Road

North Augusta, South Carolina 29841

Jim Holderness

Science Applications International Corp. 2100 Air Park Road S.E.

Albuquerque, New Mexico 87106 
This Page Intentionally Left Blank 

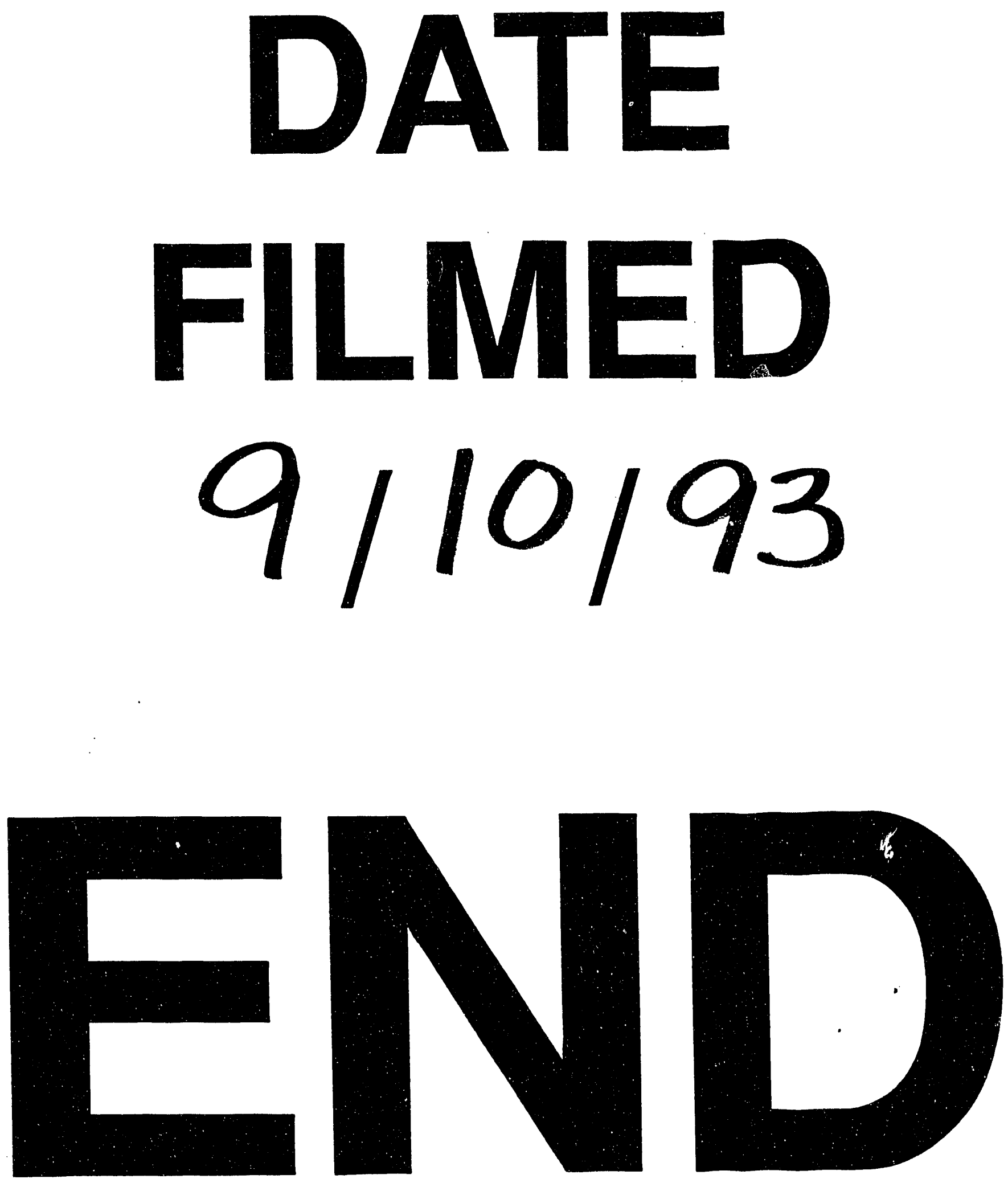
